\title{
THE IMPACT OF THE BERLIN ACCORD AND EUROPEAN ENLARGEMENT ON DAIRY MARKETS
}

\author{
Frank Fuller, John Beghin, Samarendu Mohanty, \\ Jacinto Fabiosa, Cheng Fang, and Phillip Kaus
}

\author{
Working Paper 99-WP 231 \\ December 1999
}

\author{
Center for Agricultural and Rural Development \\ lowa State University \\ Ames, IA 50011-1070
}

Frank Fuller is an international livestock analyst in the Food and Agricultural Research Institute (FAPRI), at the Center for Agricultural and Rural Development (CARD), lowa State Univesity. John C. Beghin is an associate professor, Department of Economics; co-director of FAPRI; and head of the Trade and Agricultural Policy Division, CARD, lowa State University. Samarendu Mohanty is international grain analyst, Jacinto Fabiosa is international livestock analyst, Cheng Fang is International markets analyst, and Phillip Kaus is U.S. crop and livestock analyst, in FAPRI, CARD, lowa State University.

This is a revised draft of a paper presented at the CARD-AIC Research Symposium on "National and Trade Dairy Policies. Implications for the Next WTO Negotiations" in Kansas City, Missouri, October 8-9 1999. The Authors acknowledge financial support of the Midwest Agribusiness Trade Research and Information Center. This paper is forthcoming in the Canadian Journal of Agricultural Economics.

For questions or comments about the contents of this paper, please contact, John C. Beghin, lowa State University, 568E Heady Hall, Ames, IA 50011-1070; e-mail beghin@iastate.edu; phone: 515-294-5811; fax: 515-294-6336.

lowa State University does not discriminate on the basis of race, color, age, religion, national origin, sexual orientation, sex, marital status, disability, or status as a U.S. Vietnam Era Veteran. Any persons having inquiries concerning this may contact the Director of Affirmative Action, 318 Beardshear Hall, 515-294-7612. 


\begin{abstract}
Using a world agricultural model, we analyze the impact on dairy markets of the Berlin Accord on the European Union (EU) Common Agricultural Policy (CAP) Reforms. We also investigate the consequences of enlargement of the EU to include the Czech Republic, Hungary, and Poland for the same markets. We produce a market outlook up to 2010 for these two scenarios. The Berlin Accord induces lower EU milk and dairy prices. A change in relative prices between cheese and butter-skim milk powder (SMP) occurs after 2005 and induces an expansion of cheese production, consumption, and exports at the expense of the butter-SMP sector. Accession of the three Central and Eastern European countries (CEECs) leads to a permanent but moderate decrease in EU prices of milk and dairy products. For the three acceding CEECs, domestic prices increase dramatically. Their final consumption of milk decreases and dairy product consumption drops considerably. The derived demand of milk in dairy production increases, however, because of the higher prices for dairy products, benefiting dairy producers in these CEECs. Dairy exports of the three acceding countries to the EU-15 increase by one to three orders of magnitude, despite building large inventories. The impact of accession on world markets is small.
\end{abstract}

Key words: Berlin Accord, Common Agricultural Policy, dairy markets, European Union enlargement. 


\section{THE IMPACT OF THE BERLIN ACCORD AND EUROPEAN ENLARGEMENT ON DAIRY MARKETS}

\section{Introduction}

Using a world agricultural policy analysis model, we analyze the impact of two major forthcoming changes in European policies, which will affect both European and world dairy markets. First, we consider the recent Berlin Accord, which solidifies the proposed reforms of the Common Agricultural Policy (CAP) discussed under Agenda 2000. Second, we investigate the impact of the enlargement of the European custom union to include the Czech Republic, Hungary, and Poland on dairy markets. These three Central and Eastern European countries (CEECs) have sizeable agricultural and dairy sectors.

Our analysis of the implications of the Berlin Accord and EU enlargement for the dairy sector is part of a larger and ongoing project looking at the impacts of enlarging the EU to the whole set of CEECs. Beyond the focal point of the symposium "National and Trade Dairy Policies," our paper belongs to the literature on the integration of European agriculture (Albiac and Garcia; Anderson and Tyers; Josling et al.; Leetma et al.; and Monke et al., among others).

During the Berlin European Council meeting in March 1999, European Union (EU) heads of state reached an agreement on the political and financial guidelines of the Agenda 2000 reforms of the CAP. The guidelines were officially adopted by the Council two months later in what is known as the Berlin Accord (Council of the European Union). The initial Agenda 2000 reform proposal was drafted in 1997, and, after several revisions, the proposal now constitutes the most comprehensive plan for reform of the CAP since the "MacSharry" reforms in 1991-92. As with the MacSharry reforms, the Agenda 2000 proposal and Berlin Accord are intended to reduce support for commodities through market interventions and increase support to farmers through direct payments, thereby relaxing the constraint on subsidized exports under World Trade Organization (WTO) commitments (Senior Nello and Smith). 
Although dairy will not be the sector most affected by the forthcoming CAP reforms, it will face a significant decline in support, especially after 2005. In addition, reforms in the grain and oilseed sectors will also affect dairy through their impacts on dairy feed costs. Feed cost decreases and boosts milk output per cow. Given the EU prominence in world dairy markets, the CAP reforms are likely to affect world dairy markets. We find, however, that the impact of Agenda 2000 on world markets is small.

The limited and delayed dairy reform under the Berlin Accord makes the accession of CEECs to the Union all the more interesting. Price gaps in the dairy sector between the EU-15 and the CEECs constitute a strong incentive for creating trade in dairy products from the CEECs to the EU-15. The EU-15 countries will increase their dairy imports from the acceding members when the pre-enlargement trade barriers disappear (Chevassus-Lozza et al.). Allocative efficiency should be improved. Our results confirm these conjectures.

The possibility of inducing large dairy surpluses in the CEECs by harmonizing prices has also been noted (European Commission 1999a). We address this point in our analysis. The potential expansion of dairy output in the CEECs and the likely diversion of trade towards the EU-15 suggest that the enlargement of the EU could also have consequences for prices in world

dairy markets. However, we found limited evidence of trade diversion and small impact on world dairy markets.

In the next section, we briefly present the main features of the international dairy model used to simulate the outcomes of the policy changes. Then, the specifics of the forthcoming dairy reforms are outlined, followed by a summary of the results for the Berlin Accord analysis. Using the Berlin Accord results as a point of reference, we discuss the impacts of enlarging the EU. Detailed results are presented in tables grouped in Appendix A.

\section{The Simulation Model}

The Food and Agricultural Policy Research Institute (FAPRI) modeling system is a multimarket world agricultural model. The model is extensive in terms of both its geographic and commodity coverage. Functionally, the modeling system is organized into modules according to major commodity groupings (grains, oilseeds, livestock, and dairy) with country sub-models. In 
the case of the international dairy module, each country sub-module models supply and utilization of fluid milk, butter, skim milk powder (SMP), and cheese. Whole milk powder (WMP) is included when it plays a major role in a country's dairy complex. The country submodels include a reduced-form, behavioral specification for milk domestic production, fluid consumption and the derived demands for milk used for feed, fresh dairy product output, and manufactured dairy products.

In the EU sub-model, the milk supply is equal to the quota, plus an over-quota supply response to the EU milk price net of the overproduction penalty. The available supply of milk is allocated to fluid consumption, fresh dairy products, and feed use, and the residual supply is designated as industrial milk consumption. Industrial milk is further allocated to SMP, WMP, and cheese production. Butter production is assumed to be a byproduct of the production of other manufactured and fluid milk products. We assume consumer demand for fresh dairy products is satisfied entirely by domestic production. Manufactured dairy products, however, have an explicit specification for both inventory demand and a demand for net exports. ${ }^{1}$ Domestic prices for butter, cheese, SMP, and WMP move to clear the EU market given the prevailing world prices.

Other country sub-models, including the CEECs, are structured similar to the EU submodel; however, domestic prices are not solved in these other countries. Rather, the world price is transmitted into the domestic market via a price transmission equation that includes trade distortions. Given world prices, the net export position of these countries is defined as the excess supply on the domestic market for each commodity. The excess demands and supplies of countries for each dairy product clear on the world market to determine the world price of that dairy commodity.

In addition to standard trade flows, we explicitly model trade flows between the EU-15 and Hungary, Poland, and the Czech Republic. We assume that the acceding CEECs face two export demands for their products: one from the EU-15 and the other potential member countries (i.e., the EU-18) and another from non-EU countries (e.g., Russia). As long as the CEECs are not part of the European Union, trade flows to both the EU-15 and non-EU countries enter the global market clearing condition. Trade between the CEECs and the EU-15 is specified as a constant 
proportion of total trade based on historical trade flows. Once the three CEECs join the European Union, we specify explicit export demand equations for exports to non-EU countries and calculate intra-EU-18 trade as the residual excess supply in the three new member countries. This excess supply is included in the EU-18 market clearing condition and no longer enters the global market clearing identity.

The FAPRI system captures important linkages between dairy, livestock, grain, and oilseed markets. Feed prices impact dairy supply decisions, and the dairy herd has an impact on cattle herd numbers and beef production. Both dairy and livestock animal numbers are used to determine demands for feed, which ultimately influence feed prices.

The present analysis builds on an earlier FAPRI investigation of EU dairy policies (FAPRI (1999b)). The modeling contribution in this paper is the addition of the three CEECs and the disaggregation of their trade flows toward the EU-15 and other countries. Since the primary goal of our investigation is policy analysis rather than a market outlook, we also modified the existing model to cover a more extensive set of policies.

Our model is driven by two major groups of exogenous shifters. First, the model incorporates forecasts of macroeconomic variables, such as gross domestic product (GDP), inflation rates, and exchange rates, and population. These forecasts come from Standard and Poor's DRI, Project Link, and WEFA. We also assume that average weather will prevail in the projection period. Second, important domestic agricultural and trade policy instruments are integrated into the model specification. Apart from the policy changes contained in the Agenda 2000 proposal and the enlargement scenario, domestic agricultural and commercial policies embodied in existing legislation and trade agreements are assumed to remain intact in all countries.

\section{The Berlin Accord on Agenda 2000}

\subsection{Policy Changes}

We utilized the reform proposal outlined by the Agricultural Directorate General of the European Commission (DG VI [1999a]; DG VI [1999b]), by the Council of the European Union, and the European Commission as the basis for our analysis. The proposal includes the following policy changes in the dairy sector. The current milk quota system is retained under Agenda 2000 
and will be extended until 2007/08. However, milk quotas are increased in two stages. In 2000 and 2001, quotas for Greece, Spain, Ireland, Italy, and Northern Ireland are increased to more accurately reflect current production. Quotas for all countries are increased by 1.5 percent over the three-year period beginning in 2005 . The overall quota increase will be approximately 2.4 percent over the next eight years.

Butter and SMP intervention prices are reduced by 15 percent in three equal steps beginning in 2005 (marketing year). Producers will be compensated for the price reduction by the introduction of a direct payment of 5.75 euros per metric ton in 2005, 11.49 euros per metric ton by 2006 , and 17.24 euros per metric ton in 2007 for milk delivered under the quota system. National envelopes are designated to cap additional payments at the country level. Further details of the Berlin Accord and the EU dairy industry are discussed in Benjamin, Gohin and Guyomard in this volume.

\subsection{Results on the Berlin Accord Scenario}

We simulate the implementation of the proposed CAP reforms described above, as well as the reforms scheduled for the EU grain and livestock sectors through the 2009/10 crop year. The simulation results are compared to the 1999 FAPRI world agricultural baseline (FAPRI (1999a)) to assess the impacts of the policy changes on European and international dairy markets. Table 2 presents Agenda 2000 results in levels for the EU-15. We discuss these results in relative deviations from the 1999 FAPRI baseline outlook.

The impacts of the Berlin Accord on the dairy sector are modest during the first five years of the simulation period. The increase in the milk quota in 2000 and 2001 raises milk production by less than 1 percent, depressing the milk price an average of 2.5 percent. The larger increase in the dairy quota beginning in 2005 raises milk production 1.6 percent above the baseline in 2008 . As in the baseline, dairy cow inventories are expected to decline over time in response to greater output per cow. Milk yields grow predominately in response to the technological improvements, but the 7-12 percent decline in feed costs during the first four years of the reforms boosts milk output per cow by 10-18 kg per year. The increase in the dairy quota slows the decline in EU cow inventories, leaving cow numbers 1.52 percent above the baseline level in 2008. Greater 
dairy cow inventories have a positive impact on EU beef production, but the 20 percent reduction in beef intervention prices and the release of intervention stocks keeps beef production an average of 0.5 percent below the baseline.

Butter and SMP intervention prices are reduced concurrently with the second increase in the milk quota. The combination of lower market support and increased production pushes the milk price 9.5 percent below the baseline in 2007. Butter and SMP prices decline up to 10.95 and 11.54 percent, respectively, causing milk processors to shift milk away from butter and SMP production and into cheese and WMP production.

With the Berlin Accord, EU cheese output is expected to rise by 3 percent in the outlook period, inducing a 7.6 percent decline in the domestic cheese price by 2007 compared to the projected pre Agenda 2000 projections. As a consequence, EU cheese exports are expected to rise more than 5 percent over their pre Agenda 2000 projection. Declines in SMP production coupled with increases in domestic consumption lead to a 17 percent decline in EU SMP exports in 2007 compared to pre-reform levels.

The impact on world dairy markets is predictable. World prices of dairy products decrease slightly from their baseline levels, and EU exports of cheese expand moderately throughout the outlook period. Exports of butter and SMP first increase, but then decrease after 2005, given the change in relative prices mentioned above. Finally, we find that EU price declines are a percentage point for butter, milk, and cheese of those estimated by Westhoff and Young in a similar study of the Berlin Accord. Westhoff and Young found slightly larger declines for SMP prices. This result is driven by a generally weaker price response in SMP consumption and stockholding behavior in the Westhoff and Young model.

\section{Enlargement}

\subsection{Policy Assumptions}

Although the enlargement to include CEECs has been in the making for several years, implementation is still tentative. It is difficult to anticipate the specifics of the CAP policies that will be applied in the acceding countries; however, likely adjustments can be broken down into changes in domestic policies and changes in commercial policies. Looking first at domestic 
policies, one intent of the Berlin Accord reforms is to further decouple income support and production to limit budgetary outlays (European Commission). There are conjectures that compensatory payments would not be justified for farmers in the acceding countries. These farmers would face more favorable prices following accession; however, excess agricultural labor in the new member countries may negate the impact of farm price increases as wages adjust toward EU levels (Pouliquen).

Our analysis assumes that compensatory payments, as outlined in the Berlin Accord, are extended to farmers in the exceeding countries. We do not explicitly model direct payments in the dairy sector, however, because they are assumed to be completely decoupled. They simply translate into an income transfer without first-round efficiency implications. We also omit increases in labor costs following accession, so it is as if the compensatory payments exactly offset the expected rise in agricultural wages.

We assume acceding countries will receive an initial milk production quota based on historical output, as did Austria, Finland, and Sweden when they joined the EU-12 in 1995. We take average milk deliveries in each country for the last three years prior to accession in 2003 as an approximation for the quota levels implemented in the CEECs. EU agricultural surpluses and protectionism may lead to actual policies that are different for the CEECs joining the Union, but our assumption is transparent and consistent with historical experience (see Josling et al. for a similar assumption).

We assume that after accession the acceding countries will participate with the existing EU15 countries in the forthcoming policy changes contained in the Berlin Accord. In the dairy industry, this means that the three countries receive milk quota increases of 1.5 percent starting in 2005, as do the EU-15 countries. We also assume that domestic prices and support prices in the new member countries will be harmonized with the EU-15.

In terms of trade policies, we assume that the tariff structure in the acceding CEECs is harmonized with the EU-15. They apply the EU common tariff to trade flows external to the EU18, and there is free trade within the enlarged Union. In instances when tariffs in the CEECs must be raised to meet EU-15 levels, we assume that compensation arrangements will be made under Article XXIV of the Uruguay Round Agreement on Agriculture (URAA) ${ }^{2}$. Caps on 
subsidized exports under World Trade Organization (WTO) commitments may be exacerbated by greater surpluses induced by enlargement. Policy changes in the Berlin Accord that further decouple income support and production will increase the potential for unsubsidized exports via lower European prices. For the specific case of dairy products, WTO subsidy constraints play a secondary role since the EU-15 and the three acceding countries considered in our analysis are natural exporters of dairy products. Table 1 summarizes the policy coverage and assumptions for the three acceding countries.

\subsection{Results on the EU Enlargement Scenario}

Using the Berlin Accord results as a new reference for comparison, we simulate the impacts of the Czech Republic, Hungary, and Poland joining the EU. Tables 2 and 3 show enlargement and Agenda 2000 results in levels for the EU-15 and the Czech Republic, respectively. Further results for Hungary and Poland are discussed in the appendix tables.

In summary, the accession increases domestic prices for milk and dairy products to the new EU-18 levels in the three CEECs. Domestic final demand decreases, especially for dairy products. Significant increases in feed costs, as well as the imposition of marketing quotas, dampen the growth in milk production in the CEECs, particularly in Poland. Nevertheless, production of dairy products in the CEECs expands, and exports to the EU-15 increase considerably. Given the higher domestic prices, CEEC exports to nonEU countries decrease, which represents a case of trade diversion. For most of the CEECs, these trade flows were small prior to accession, so the changes have little impact on world markets. Consumers in the EU-15 benefit from lower food prices, and export demand for EU products expands beyond the level induced by Agenda 2000. The impact on world markets of the three CEECs accession is almost negligible. World prices in most years change by less than 1 percent compared to their Agenda 2000 levels.

The EU-15 dairy exports, excluding trade with the CEECs, increase significantly with respect to their levels under Agenda 2000. Greater exports are possible because domestic consumers substitute some indigenous dairy products for imports from the new member countries. Stock levels rise to absorb some of the displaced domestic production, but excess 
supplies within the expanded Union prompt butter, cheese, and SMP prices to fall and EU-15 exports to rise. We exogenously impose an increase in the ending stock of dairy products in the three acceding countries. This assumption is motivated by the questionable political feasibility of unconstrained export expansion toward the EU-15. We assume that 50 percent of the change in exports to the EU-15 goes into inventory. In addition, we assume that expenditures on export subsidies in the Czech Republic will be pushed to their maximum allowed under the URAA, less the estimated expenditures on subsidies to the EU-15 prior to accession. Increasing export subsidies minimizes trade diversion in the Czech Republic. These assumptions could be easily relaxed and would just make our qualitative results on EU prices and intra-trade more pronounced.

Between 2003 and 2010 internal EU prices for cheese, butter, SMP, and WMP fall by 2.4 to 5.9 percent compared to their Agenda 2000 levels. The value of the milk used to produce these products consequently falls, mimicking the changes in dairy product prices and falling by comparable magnitude with respect to their Agenda 2000 levels. EU export prices follow the world prices for dairy products and, thus, are largely unaffected by the enlargement to include the three CEECs.

In the Czech Republic, the milk quota is set at the average historical level for milk deliveries, and it largely determines milk production after accession. Some additional production occurs because of the increases in output price relative to feed costs, but most of the excess production is used for feed and is not marketed under quota. Milk consumption drops by 10.7 percent the first year of accession, compared to the Agenda 2000 level. Consumption gradually rises and stabilizes roughly 4.6 percent below the pre-accession levels. Similarly, domestic consumption of cheese, butter, and SMP initially decreases by 7.8, 4.2, and 11.3 percent, respectively, then slowly converges toward levels 2 to 6 percent below the pre-accession projection. Although not calculated here, losses of consumer surplus are considerable, given the inelastic nature of food demand. Domestic prices for milk, cheese, butter, and SMP initially increase by $35.5,68.8,95.1$, and 80.5 percent respectively! Despite higher fluid milk prices, the derived demand for milk in cheese, butter, and industrial use expands significantly because of the 
higher prices for dairy products in the Czech Republic. Dairy exports to the EU-15 expand dramatically but the new levels are still quite small, compared to the size of the EU market.

In Hungary and Poland, similar patterns occur. Poland is the largest producer of milk among the three countries joining the EU. The notable difference is its consumption of fluid milk, which is the highest among the three CEECs and is a bit more price responsive than consumption in the other two countries. Unlike the Czech Republic and Hungary, Poland was a significant exporter of dairy products, particularly SMP and cheese. With the dramatic rise in domestic Polish prices following accession, Polish exports to non-EU-18 countries drop dramatically, causing a slight rise in the world SMP price in 2003 and 2004. We refer the interested reader to appendix A for further details on the Czech Republic, Hungary, and Poland.

With the usual caveat of partial equilibrium analysis, major losers appear to be net food consumers in the three acceding countries. Producers in the EU-15 also suffer minor losses, but the declines in dairy product output in the EU-15 are generally less than 1 percent. This conclusion abstracts from positive income and efficiency effects that are likely to result from the integration in the European market.

\section{Concluding Remarks}

The CAP reforms resulting from the Berlin Accord are likely to create substantial changes in European agricultural markets. Policy changes in the dairy sector will lower dairy product prices between 5 and 15 percent. Expansion in EU milk output will be channeled predominately into cheese production, lowering EU prices and increasing cheese exports.

The enlargement of the European customs union to the Czech Republic, Hungary, and Poland would provide a major shock to European dairy markets, especially given their sizeable agricultural sectors. We found that accession of these three countries leads to a permanent but moderate decrease in EU prices of milk and dairy products. For the three former CEECs, these prices are much higher than pre-accession domestic prices.

In the three CEECs, final consumption of milk drops drastically. The derived demand for milk for dairy products increases, however, because of the higher prices for dairy products, benefiting dairy producers but penalizing consumers severely. Final consumption of dairy 
products in the three acceding countries decreases precipitously. This result abstracts from other gains to consumers from integration and deepening of markets (See Baldwin et al.). Exports to the former EU-15 increase by one to three orders of magnitude, despite the imposition of building large inventories.

The impact of accession on world market prices is negligible, except for some trade diversion occurring in the three CEECs with accession. The three new members contribute significantly to EU intra-trade and induce lower prices in the former EU-15 market. This effect has been dampened in our model because of our prior belief that it would be politically infeasible to allow unrestrained expansion of exports into the EU-15, forcing stocks to rise in the CEECs. Finally, we note that our results are qualitatively similar to results found by Chevassus-Lozza et al. in their analysis of the accession of the whole set of CEECs.

As explained at the beginning of the paper, the results reported in this analysis are dependent on series of assumptions relating to the functioning of EU markets and to the future world agricultural and macro-economic situations. In addition, the specific modalities of accession of the three CEECs considered here are not known. We have attempted to make transparent yet reasonable assumptions on how this accession would occur. Changes in the underlying assumptions could invalidate or alter the results reported in this study. 

Table 1. Policy summary for enlargement to Czech Republic, Hungary, and Poland

\section{Czech Republic}

Milk Quota

Agenda 2000

0

Enlargement

2001

2002

2003

2004

2005

2006

2007

2008

2009

2010

Direct Dairy Payments

Agenda $2000 \quad 0 \quad 0$

Enlargement $\quad 0 \quad 0$

Preferential Tariff Rates

Thousand MT

Butter

$\begin{array}{lllllllllll}\text { Agenda 2000 } & 32 & 32 & 32 & 32 & 32 & 32 & 32 & 32 & 32 & 32 \\ \text { Enlargement } & 32 & 32 & 38 & 38 & 36 & 36 & 35 & 35 & 35 & 35\end{array}$

Cheese

Agenda 2000

Enlargement

9

9

SMP

Agenda 2000

$37 \quad 37$

Enlargement

$37 \quad 37$

Average Export Subsidy

Butter

$\begin{array}{lllllllllll}\begin{array}{l}\text { Agenda 2000 } \\ \text { Enlargement }\end{array} & 1.42 & 1.42 & 1.42 & 1.42 & 1.42 & 1.42 & 1.42 & 1.42 & 1.42 & 1.42 \\ \text { Cheese } & 1.42 & 1.42 & 3.04 & 3.13 & 3.03 & 2.97 & 2.89 & 3.02 & 3.06 & 3.10 \\ \text { Agenda 2000 } & 1.42 & 1.42 & 1.42 & 1.42 & 1.42 & 1.42 & 1.42 & 1.42 & 1.42 & 1.42 \\ \quad \text { Enlargement } & 1.42 & 1.42 & 3.04 & 3.13 & 3.03 & 2.97 & 2.89 & 3.02 & 3.06 & 3.10 \\ \text { SMP } & & & & & & & & & & \\ \text { Agenda 2000 } & 1.42 & 1.42 & 1.42 & 1.42 & 1.42 & 1.42 & 1.42 & 1.42 & 1.42 & 1.42 \\ \text { Enlargement } & 1.42 & 1.42 & 3.24 & 3.22 & 3.23 & 3.20 & 2.96 & 3.03 & 3.13 & 3.20\end{array}$

Total Subsidy Expenditures

Million Koruny

SMP

$\begin{array}{lrrrrrrrrrr}\text { Agenda 2000 } & 270 & 257 & 241 & 223 & 208 & 194 & 182 & 172 & 162 & 151 \\ \text { Enlargement } & 270 & 257 & 807 & 791 & 860 & 921 & 894 & 910 & 972 & 1007 \\ \text { WT Commitment } & 1246 & 1246 & 1246 & 1246 & 1246 & 1246 & 1246 & 1246 & 1246 & 1246 \\ \text { Butter and Cheese } & & & & & & & & & & \\ \text { Agenda 2000 } & 790 & 753 & 703 & 652 & 607 & 569 & 538 & 511 & 487 & 463 \\ \text { Enlargement } & 790 & 753 & 949 & 978 & 987 & 994 & 974 & 1014 & 972 & 928 \\ \text { WTO Commitment } & 1280 & 1280 & 1280 & 1280 & 1280 & 1280 & 1280 & 1280 & 1280 & 1280\end{array}$


Table 1: Policy summary for enlargement to Czech Republic, Hungary, and Poland (Cont.)

\begin{tabular}{llllllllll}
\hline 2001 & 2002 & 2003 & 2004 & 2005 & 2006 & 2007 & 2008 & 2009 & 2010 \\
\hline
\end{tabular}

\section{Hungary}

Milk Quota

Enlargement

1900

1900

Direct Dairy Payments

$\begin{array}{llll}\text { Agenda 2000 } & 0 & 0 & 0 \\ \text { Enlargement } & 0 & 0 & 0\end{array}$

Preferential Tariff Rates

Butter

Agenda 2000

Enlargement

$$
60
$$

$$
60
$$

60

60

60

38

Cheese

Agenda 2000

Enlargement

$\begin{array}{lll}50 & 50 & 50 \\ 50 & 50 & 20\end{array}$

SMP

Agenda 2000

$51 \quad 51$

Enlargement

\section{Poland}

\section{Milk Quota}

Agenda 2000

Enlargement

$$
51
$$

$51 \quad 19$

Thousand MT

$\begin{array}{lllllll}1900 & 1900 & 1900 & 1900 & 1900 & 1900 & 1900 \\ 1900 & 1910 & 1919 & 1929 & 1929 & 1929 & 1929\end{array}$

Million Florint

$\begin{array}{rrrrrrr}0 & 0 & 0 & 0 & 0 & 0 & 0 \\ 0 & 4055 & 8453 & 13202 & 13665 & 14144 & 14640\end{array}$

Percent Ad Valorem

Direct Dairy Payments

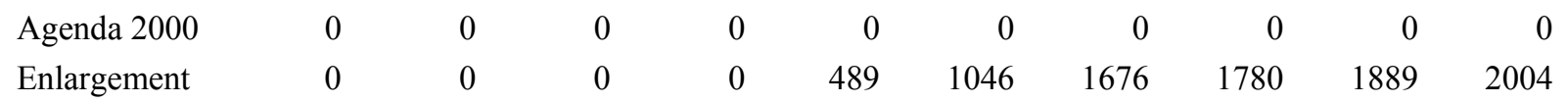

\section{Preferential Tariff Rates}

Percent Ad Valorem

Butter

$\begin{array}{lllllllllll}\text { Agenda 2000 } & 40 & 40 & 40 & 40 & 40 & 40 & 40 & 40 & 40 & 40 \\ \text { Enlargement } & 40 & 40 & 38 & 38 & 36 & 36 & 35 & 35 & 35 & 35\end{array}$

Cheese

\begin{tabular}{lllllllllll} 
Agenda 2000 & 35 & 35 & 35 & 35 & 35 & 35 & 35 & 35 & 35 & 35 \\
Enlargement & 35 & 35 & 20 & 20 & 20 & 20 & 20 & 20 & 20 & 19 \\
SMP & & & & & & & & & & \\
Agenda 2000 & 40 & 40 & 40 & 40 & 40 & 40 & 40 & 40 & 40 & 40 \\
Enlargement & 40 & 40 & 19 & 19 & 19 & 19 & 18 & 17 & 16 & 16 \\
\hline
\end{tabular}


Table 2. Impacts of EU enlargement on EU milk, butter, and cheese

\begin{tabular}{|c|c|c|c|c|c|c|c|c|c|c|}
\hline & 2001 & 2002 & 2003 & 2004 & 2005 & 2006 & 2007 & 2008 & 2009 & 2010 \\
\hline Milk Production & & & & & (Thousa & nd MT) & & & & \\
\hline Agenda 2000 & 121,514 & 121,471 & 121,405 & 121,361 & 121,723 & 122,014 & 122,300 & 122,177 & 122,163 & 122,166 \\
\hline Enlargement & 121,514 & 121,471 & 121,323 & 121,120 & 121,394 & 121,686 & 122,003 & 121,922 & 121,935 & 121,948 \\
\hline \multicolumn{11}{|l|}{ Fluid Milk Cons. } \\
\hline Agenda 2000 & 32,377 & 32,284 & 32,174 & 32,040 & 32,046 & 32,021 & 32,015 & 31,850 & 31,700 & 31,555 \\
\hline Enlargement & 32,377 & 32,284 & 32,358 & 32,353 & 32,372 & 32,330 & 32,289 & 32,101 & 31,935 & 31,780 \\
\hline Milk Price & \multicolumn{10}{|c|}{$(\mathrm{ECU} / 100 \mathrm{Kg})$} \\
\hline Agenda 2000 & 29 & 29 & 29 & 29 & 29 & 29 & 28 & 29 & 29 & 29 \\
\hline Enlargement & 29 & 29 & 28 & 28 & 27 & 27 & 27 & 27 & 28 & 28 \\
\hline Butter Production & \multicolumn{10}{|c|}{ (Thousand MT) } \\
\hline Agenda 2000 & 1,784 & 1,779 & 1,774 & 1,773 & 1,764 & 1,758 & 1,746 & 1,747 & 1,746 & 1,744 \\
\hline Enlargement & 1,784 & 1,779 & 1,775 & 1,767 & 1,753 & 1,746 & 1,736 & 1,739 & 1,741 & 1,741 \\
\hline \multicolumn{11}{|l|}{ Butter Consumption } \\
\hline Agenda 2000 & 1,639 & 1,637 & 1,633 & 1,631 & 1,647 & 1,656 & 1,667 & 1,658 & 1,652 & 1,647 \\
\hline Enlargement & 1,639 & 1,637 & 1,637 & 1,641 & 1,663 & 1,672 & 1,684 & 1,675 & 1,669 & 1,664 \\
\hline \multicolumn{11}{|c|}{ Butter Net Exports (Excl. Vis. 3) } \\
\hline Agenda 2000 & 138 & 146 & 149 & 151 & 144 & 132 & 115 & 107 & 105 & 105 \\
\hline Enlargement & 138 & 146 & 152 & 158 & 154 & 144 & 127 & 119 & 117 & 116 \\
\hline \multicolumn{11}{|c|}{ Butter Net Exports to Vis. 3} \\
\hline Agenda 2000 & -1 & -1 & -2 & -2 & -2 & -2 & -1 & -1 & -1 & -1 \\
\hline Enlargement & -1 & -1 & -41 & -59 & -53 & -46 & -39 & -35 & -32 & -30 \\
\hline \multicolumn{11}{|l|}{ Cheese Production } \\
\hline Agenda 2000 & 6,153 & 6,210 & 6,266 & 6,317 & 6,424 & 6,516 & 6,619 & 6,654 & 6,708 & 6,768 \\
\hline Enlargement & 6,153 & 6,210 & 6,223 & 6,258 & 6,370 & 6,467 & 6,574 & 6,610 & 6,661 & 6,717 \\
\hline \multicolumn{11}{|l|}{ Cheese Consumption } \\
\hline Agenda 2000 & 5,838 & 5,897 & 5,953 & 6,003 & 6,091 & 6,176 & 6,268 & 6,317 & 6,369 & 6,421 \\
\hline Enlargement & 5,838 & 5,897 & 6,025 & 6,119 & 6,209 & 6,288 & 6,367 & 6,408 & 6,454 & 6,503 \\
\hline \multicolumn{11}{|c|}{ Cheese Net Exports to Vis. 3} \\
\hline Agenda 2000 & -21 & -18 & -17 & -12 & -8 & -3 & 0 & 3 & 5 & 6 \\
\hline Enlargement & -21 & -18 & -167 & -235 & -228 & -217 & -203 & -197 & -193 & -188 \\
\hline \multicolumn{11}{|l|}{ Dairy Prices } \\
\hline EU Cheese Price & \multicolumn{10}{|c|}{$(\mathrm{ECU} / 100 \mathrm{~kg})$} \\
\hline Agenda 2000 & 465 & 468 & 471 & 477 & 473 & 470 & 465 & 471 & 477 & 483 \\
\hline Enlargement & 465 & 468 & 455 & 450 & 445 & 443 & 441 & 448 & 455 & 462 \\
\hline \multicolumn{11}{|l|}{ EU Butter Price } \\
\hline Agenda 2000 & 353 & 353 & 355 & 357 & 345 & 337 & 327 & 331 & 334 & 337 \\
\hline Enlargement & 353 & 353 & 346 & 340 & 326 & 318 & 309 & 314 & 317 & 319 \\
\hline Cheese, FOB N. Eur. & \multicolumn{10}{|c|}{ (U.S. Dollars/MT) } \\
\hline Agenda 2000 & 2,430 & 2,431 & 2,432 & 2,450 & 2,447 & 2,444 & 2,451 & 2,446 & 2,458 & 2,520 \\
\hline Enlargement & 2,430 & 2,431 & 2,457 & 2,435 & 2,428 & 2,427 & 2,446 & 2,454 & 2,469 & 2,514 \\
\hline \multicolumn{11}{|l|}{ Butter, FOB N. Eur. } \\
\hline Agenda 2000 & 1,746 & 1,765 & 1,791 & 1,815 & 1,864 & 1,888 & 1,890 & 1,887 & 1,884 & 1,870 \\
\hline Enlargement & 1,746 & 1,765 & 1,789 & 1,799 & 1,844 & 1,878 & 1,884 & 1,884 & 1,881 & 1,862 \\
\hline
\end{tabular}


Table 3. Impacts of EU enlargement on Czech Republic milk, butter, and cheese

\begin{tabular}{|c|c|c|c|c|c|c|c|c|c|c|}
\hline & 2001 & 2002 & 2003 & 2004 & 2005 & 2006 & 2007 & 2008 & 2009 & 2010 \\
\hline \multicolumn{11}{|l|}{ Milk } \\
\hline Milk Production & & & & & (Thousa & d MT) & & & & \\
\hline Agenda 2000 & 2,831 & 2,822 & 2,795 & 2,763 & 2,737 & 2,721 & 2,719 & 2,730 & 2,751 & 2,781 \\
\hline Enlargement & 2,831 & 2,822 & 3,095 & 3,128 & 2,973 & 2,960 & 2,925 & 2,900 & 2,880 & 2,862 \\
\hline \multicolumn{11}{|l|}{ Fluid Milk Cons. } \\
\hline Agenda 2000 & 313 & 323 & 333 & 343 & 353 & 362 & 372 & 381 & 391 & 401 \\
\hline Enlargement & 313 & 323 & 298 & 313 & 328 & 342 & 355 & 364 & 373 & 384 \\
\hline Domestic Milk Prices & \multicolumn{10}{|c|}{ (Koruny/kg) } \\
\hline Agenda 2000 & 8.6 & 8.2 & 7.9 & 7.8 & 7.6 & 7.6 & 7.5 & 7.5 & 7.5 & 7.5 \\
\hline Enlargement & 8.6 & 8.2 & 10.8 & 10.2 & 9.7 & 9.4 & 9.1 & 9.2 & 9.3 & 9.3 \\
\hline Change & 0.00 & 0.00 & 2.82 & 2.46 & 2.09 & 1.85 & 1.59 & 1.71 & 1.79 & 1.83 \\
\hline$\%$ Change & $0.0 \%$ & $0.0 \%$ & $35.5 \%$ & $31.7 \%$ & $27.4 \%$ & $24.5 \%$ & $21.1 \%$ & $22.7 \%$ & $23.9 \%$ & $24.3 \%$ \\
\hline \multicolumn{11}{|l|}{ Butter } \\
\hline Butter Production & \multicolumn{10}{|c|}{ (Thousand MT) } \\
\hline Agenda 2000 & 70 & 69 & 68 & 66 & 65 & 64 & 64 & 63 & 63 & 62 \\
\hline Enlargement & 70 & 69 & 74 & 73 & 68 & 67 & 65 & 64 & 63 & 62 \\
\hline \multicolumn{11}{|l|}{ Butter Consumption } \\
\hline Agenda 2000 & 48 & 48 & 49 & 49 & 49 & 49 & 50 & 50 & 50 & 51 \\
\hline Enlargement & 48 & 48 & 47 & 47 & 48 & 48 & 49 & 49 & 49 & 50 \\
\hline \multicolumn{11}{|c|}{ Butter Net Exports to EU-18 } \\
\hline Agenda 2000 & 1 & 1 & 1 & 1 & 1 & 1 & 1 & 1 & 1 & 1 \\
\hline Enlargement & 1 & 1 & 10 & 12 & 9 & 6 & 4 & 2 & 1 & 0 \\
\hline Domestic Butter Price & \multicolumn{10}{|c|}{ (Koruny/kg) } \\
\hline Agenda 2000 & 85.6 & 82.1 & 80.0 & 78.4 & 78.5 & 77.9 & 76.7 & 76.0 & 75.4 & 74.3 \\
\hline Enlargement & 85.6 & 82.1 & 135.0 & 127.7 & 118.9 & 113.3 & 108.2 & 108.9 & 109.2 & 109.1 \\
\hline \multicolumn{11}{|l|}{ Cheese } \\
\hline Cheese Production & \multicolumn{10}{|c|}{ (Thousand MT) } \\
\hline Agenda 2000 & 80 & 80 & 79 & 78 & 77 & 76 & 76 & 76 & 77 & 78 \\
\hline Enlargement & 80 & 80 & 99 & 99 & 90 & 91 & 89 & 89 & 88 & 87 \\
\hline \multicolumn{11}{|l|}{ Cheese Consumption } \\
\hline Agenda 2000 & 77 & 79 & 80 & 81 & 83 & 84 & 85 & 86 & 87 & 88 \\
\hline Enlargement & 77 & 79 & 74 & 76 & 78 & 79 & 81 & 82 & 83 & 84 \\
\hline \multicolumn{11}{|c|}{ Cheese Net Exports to EU-18 } \\
\hline Agenda 2000 & 7 & 5 & 2 & 0 & -2 & -4 & -6 & -7 & -7 & -6 \\
\hline Enlargement & 7 & 5 & 30 & 36 & 32 & 30 & 27 & 25 & 23 & 21 \\
\hline Domestic Cheese Price & \multicolumn{10}{|c|}{ (Koruny/kg) } \\
\hline Agenda 2000 & 102.1 & 95.7 & 91.0 & 87.9 & 85.2 & 82.9 & 81.5 & 80.5 & 80.1 & 81.1 \\
\hline Enlargement & 102.1 & 95.7 & 177.5 & 168.9 & 162.4 & 157.9 & 154.3 & 155.7 & 156.8 & 157.8 \\
\hline
\end{tabular}


Appendix A 


\begin{tabular}{|c|c|c|c|c|c|c|c|c|c|c|}
\hline & 2001 & 2002 & 2003 & 2004 & 2005 & 2006 & 2007 & 2008 & 2009 & 2010 \\
\hline Milk Production & \multicolumn{10}{|c|}{ (Thousand MT) } \\
\hline Agenda 2000 & 121,514 & 121,471 & 121,405 & 121,361 & 121,723 & 122,014 & 122,300 & 122,177 & 122,163 & 122,166 \\
\hline Enlargement & 121,514 & 121,471 & 121,323 & 121,120 & 121,394 & 121,686 & 122,003 & 121,922 & 121,935 & 121,948 \\
\hline$\%$ Change & $0.0 \%$ & $0.0 \%$ & $-0.1 \%$ & $-0.2 \%$ & $-0.3 \%$ & $-0.3 \%$ & $-0.2 \%$ & $-0.2 \%$ & $-0.2 \%$ & $-0.2 \%$ \\
\hline \multicolumn{11}{|l|}{ Milk Deliveries } \\
\hline Agenda 2000 & 118,219 & 118,239 & 118,238 & 118,253 & 118,664 & 119,006 & 119,345 & 119,279 & 119,323 & 119,382 \\
\hline Enlargement & 118,219 & 118,239 & 118,155 & 118,012 & 118,337 & 118,680 & 119,050 & 119,022 & 119,090 & 119,157 \\
\hline$\%$ Change & $0.0 \%$ & $0.0 \%$ & $-0.1 \%$ & $-0.2 \%$ & $-0.3 \%$ & $-0.3 \%$ & $-0.2 \%$ & $-0.2 \%$ & $-0.2 \%$ & $-0.2 \%$ \\
\hline Fluid Milk Cons. & \multicolumn{10}{|c|}{ (Thousand MT) } \\
\hline Agenda 2000 & 32,377 & 32,284 & 32,174 & 32,040 & 32,046 & 32,021 & 32,015 & 31,850 & 31,700 & 31,555 \\
\hline Enlargement & 32,377 & 32,284 & 32,358 & 32,353 & 32,372 & 32,330 & 32,289 & 32,101 & 31,935 & 31,780 \\
\hline$\%$ Change & $0.0 \%$ & $0.0 \%$ & $0.6 \%$ & $1.0 \%$ & $1.0 \%$ & $1.0 \%$ & $0.9 \%$ & $0.8 \%$ & $0.7 \%$ & $0.7 \%$ \\
\hline Milk Price & \multicolumn{10}{|c|}{$(\mathrm{ECU} / 100 \mathrm{Kg})$} \\
\hline Agenda 2000 & 29 & 29 & 29 & 29 & 29 & 29 & 28 & 29 & 29 & 29 \\
\hline Enlargement & 29 & 29 & 28 & 28 & 27 & 27 & 27 & 27 & 28 & 28 \\
\hline$\%$ Change & $0.0 \%$ & $0.0 \%$ & $-3.2 \%$ & $-5.6 \%$ & $-6.0 \%$ & $-5.9 \%$ & $-5.4 \%$ & $-5.0 \%$ & $-4.7 \%$ & $-4.5 \%$ \\
\hline
\end{tabular}




\section{Impacts of EU enlargement on EU butter}

\begin{tabular}{|c|c|c|c|c|c|c|c|c|c|c|}
\hline & 2001 & 2002 & 2003 & 2004 & 2005 & 2006 & 2007 & 2008 & 2009 & 2010 \\
\hline \multicolumn{5}{|c|}{ Butter Production } & \multicolumn{3}{|c|}{ (Thousand MT) } & & & \\
\hline Agenda 2000 & 1,784 & 1,779 & 1,774 & 1,773 & 1,764 & 1,758 & 1,746 & 1,747 & 1,746 & 1,744 \\
\hline Enlargement & 1,784 & 1,779 & 1,775 & 1,767 & 1,753 & 1,746 & 1,736 & 1,739 & 1,741 & 1,741 \\
\hline$\%$ Change & $0.0 \%$ & $0.0 \%$ & $0.1 \%$ & $-0.3 \%$ & $-0.6 \%$ & $-0.7 \%$ & $-0.6 \%$ & $-0.5 \%$ & $-0.3 \%$ & $-0.2 \%$ \\
\hline \multicolumn{11}{|c|}{ Butter Consumption } \\
\hline Agenda 2000 & 1,639 & 1,637 & 1,633 & 1,631 & 1,647 & 1,656 & 1,667 & 1,658 & 1,652 & 1,647 \\
\hline Enlargement & 1,639 & 1,637 & 1,637 & 1,641 & 1,663 & 1,672 & 1,684 & 1,675 & 1,669 & 1,664 \\
\hline$\%$ Change & $0.0 \%$ & $0.0 \%$ & $0.2 \%$ & $0.7 \%$ & $0.9 \%$ & $1.0 \%$ & $1.0 \%$ & $1.0 \%$ & $1.0 \%$ & $1.0 \%$ \\
\hline \multicolumn{11}{|c|}{ Butter Net Exports (Excl. Vis. 3) } \\
\hline Agenda 2000 & 138 & 146 & 149 & 151 & 144 & 132 & 115 & 107 & 105 & 105 \\
\hline Enlargement & 138 & 146 & 152 & 158 & 154 & 144 & 127 & 119 & 117 & 116 \\
\hline$\%$ Change & $0.0 \%$ & $0.0 \%$ & $2.4 \%$ & $4.7 \%$ & $6.5 \%$ & $8.7 \%$ & $10.6 \%$ & $11.4 \%$ & $11.4 \%$ & $10.5 \%$ \\
\hline \multicolumn{11}{|c|}{ Butter Net Exports to Vis. 3} \\
\hline Agenda 2000 & -1 & -1 & -2 & -2 & -2 & -2 & -1 & -1 & -1 & -1 \\
\hline $\begin{array}{l}\text { Enlargement } \\
\%\end{array}$ & -1 & -1 & -41 & -59 & -53 & -46 & -39 & -35 & -32 & -30 \\
\hline Change & $0.0 \%$ & $0.0 \%$ & $2409.5 \%$ & $3284.3 \%$ & $2993.5 \%$ & $2708.6 \%$ & $2677.2 \%$ & $2916.0 \%$ & $4826.8 \%$ & $3889.3 \%$ \\
\hline
\end{tabular}


Impacts of EU enlargement on EU cheese

\begin{tabular}{|c|c|c|c|c|c|c|c|c|c|c|}
\hline & 2001 & 2002 & 2003 & 2004 & 2005 & 2006 & 2007 & 2008 & 2009 & 2010 \\
\hline \multicolumn{5}{|c|}{ Cheese Production } & \multicolumn{3}{|c|}{ (Thousand MT) } & & & \\
\hline Agenda 2000 & 6,153 & 6,210 & 6,266 & 6,317 & 6,424 & 6,516 & 6,619 & 6,654 & 6,708 & 6,768 \\
\hline Enlargement & 6,153 & 6,210 & 6,223 & 6,258 & 6,370 & 6,467 & 6,574 & 6,610 & 6,661 & 6,717 \\
\hline$\%$ Change & $0.0 \%$ & $0.0 \%$ & $-0.7 \%$ & $-0.9 \%$ & $-0.8 \%$ & $-0.7 \%$ & $-0.7 \%$ & $-0.7 \%$ & $-0.7 \%$ & $-0.8 \%$ \\
\hline \multicolumn{11}{|c|}{ Cheese Consumption } \\
\hline Agenda 2000 & 5,838 & 5,897 & 5,953 & 6,003 & 6,091 & 6,176 & 6,268 & 6,317 & 6,369 & 6,421 \\
\hline Enlargement & 5,838 & 5,897 & 6,025 & 6,119 & 6,209 & 6,288 & 6,367 & 6,408 & 6,454 & 6,503 \\
\hline$\%$ Change & $0.0 \%$ & $0.0 \%$ & $1.2 \%$ & $1.9 \%$ & $2.0 \%$ & $1.8 \%$ & $1.6 \%$ & $1.4 \%$ & $1.3 \%$ & $1.3 \%$ \\
\hline \multicolumn{11}{|c|}{ Cheese Net Exports (Excl. Vis. 3) } \\
\hline Agenda 2000 & 330 & 329 & 314 & 317 & 324 & 331 & 341 & 340 & 342 & 350 \\
\hline Enlargement & 330 & 329 & 350 & 365 & 378 & 389 & 402 & 405 & 406 & 407 \\
\hline$\%$ Change & $0.0 \%$ & $0.0 \%$ & $11.6 \%$ & $15.4 \%$ & $16.8 \%$ & $17.6 \%$ & $18.1 \%$ & $19.1 \%$ & $18.6 \%$ & $16.1 \%$ \\
\hline \multicolumn{11}{|c|}{ Cheese Net Exports to Vis. 3} \\
\hline Agenda 2000 & -21 & -18 & -17 & -12 & -8 & -3 & 0 & 3 & 5 & 6 \\
\hline Enlargement & -21 & -18 & -167 & -235 & -228 & -217 & -203 & -197 & -193 & -188 \\
\hline$\%$ Change & $0.0 \%$ & $0.0 \%$ & $892.0 \%$ & $1801.4 \%$ & $2703.9 \%$ & $7110.3 \%$ & NA & $-6060.9 \%$ & $-4281.5 \%-3$ & $3013.3 \%$ \\
\hline
\end{tabular}


Impacts of EU enlargement on EU milk powder

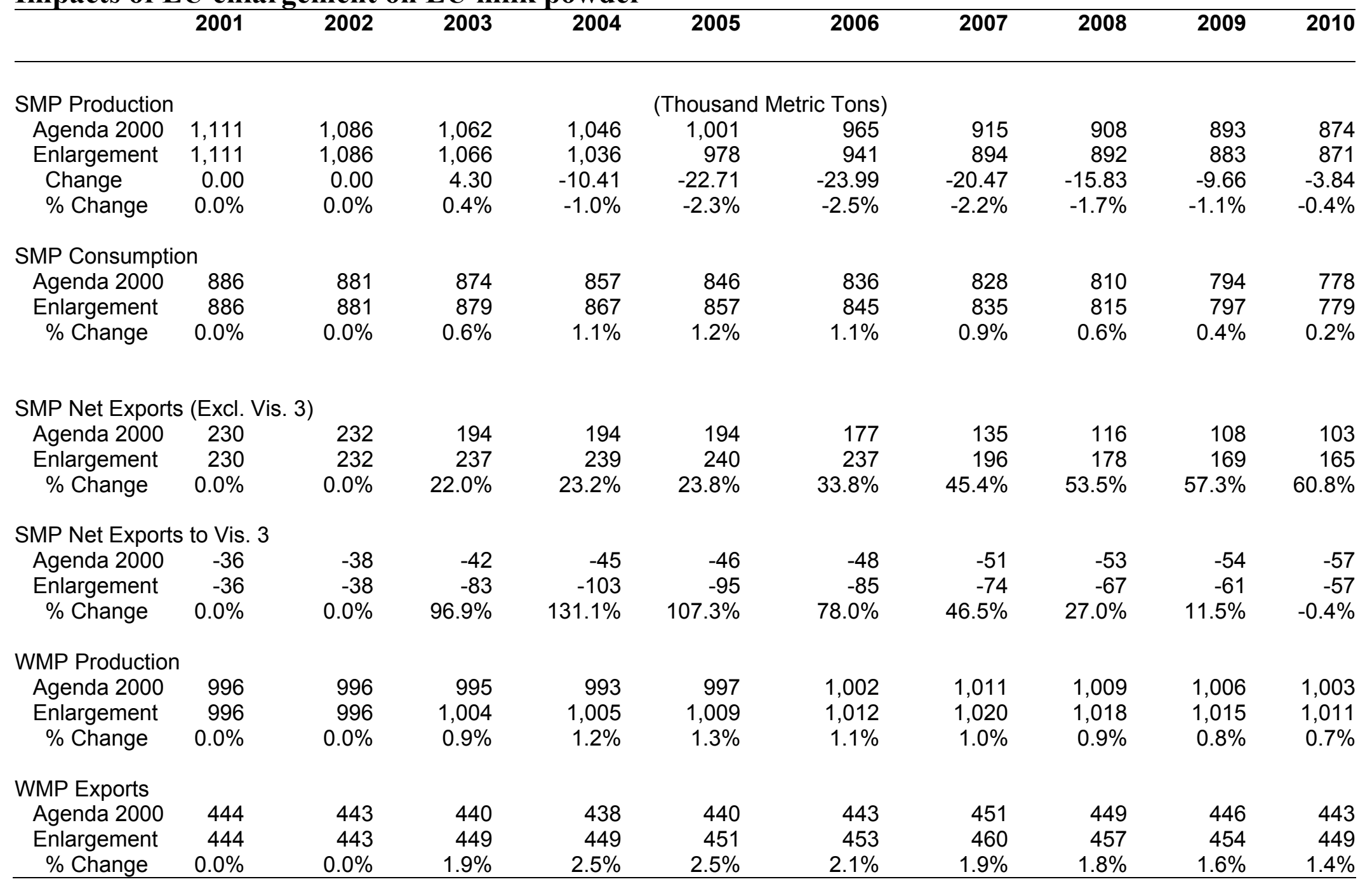




\section{Impacts of EU enlargement on EU dairy prices}

\begin{tabular}{|c|c|c|c|c|c|c|c|c|c|c|}
\hline & 2001 & 2002 & 2003 & 2004 & 2005 & 2006 & 2007 & 2008 & 2009 & 2010 \\
\hline EU Milk Price & & & & & $(\mathrm{ECU} / 100 \mathrm{~kg}$ & & & & & \\
\hline Agenda 2000 & 29 & 29 & 29 & 29 & 29 & 29 & 28 & 29 & 29 & 29 \\
\hline Enlargement & 29 & 29 & 28 & 28 & 27 & 27 & 27 & 27 & 28 & 28 \\
\hline$\%$ Change & $0.0 \%$ & $0.0 \%$ & $-3.2 \%$ & $-5.6 \%$ & $-6.0 \%$ & $-5.9 \%$ & $-5.4 \%$ & $-5.0 \%$ & $-4.7 \%$ & $-4.5 \%$ \\
\hline \multicolumn{11}{|l|}{ EU Cheese } \\
\hline \multicolumn{11}{|l|}{ Price } \\
\hline Agenda 2000 & 465 & 468 & 471 & 477 & 473 & 470 & 465 & 471 & 477 & 483 \\
\hline Enlargement & 465 & 468 & 455 & 450 & 445 & 443 & 441 & 448 & 455 & 462 \\
\hline$\%$ Change & $0.0 \%$ & $0.0 \%$ & $-3.4 \%$ & $-5.6 \%$ & $-5.9 \%$ & $-5.7 \%$ & $-5.2 \%$ & $-4.8 \%$ & $-4.5 \%$ & $-4.4 \%$ \\
\hline \multicolumn{11}{|l|}{ EU Butter Price } \\
\hline Agenda 2000 & 353 & 353 & 355 & 357 & 345 & 337 & 327 & 331 & 334 & 337 \\
\hline Enlargement & 353 & 353 & 346 & 340 & 326 & 318 & 309 & 314 & 317 & 319 \\
\hline$\%$ Change & $0.0 \%$ & $0.0 \%$ & $-2.5 \%$ & $-4.7 \%$ & $-5.6 \%$ & $-5.7 \%$ & $-5.5 \%$ & $-5.3 \%$ & $-5.2 \%$ & $-5.1 \%$ \\
\hline \multicolumn{11}{|l|}{ EU SMP Price } \\
\hline Agenda 2000 & 205 & 204 & 205 & 208 & 205 & 202 & 198 & 201 & 204 & 206 \\
\hline Enlargement & 205 & 204 & 199 & 197 & 193 & 191 & 189 & 194 & 197 & 201 \\
\hline$\%$ Change & $0.0 \%$ & $0.0 \%$ & $-2.9 \%$ & $-5.3 \%$ & $-5.6 \%$ & $-5.3 \%$ & $-4.6 \%$ & $-3.8 \%$ & $-3.2 \%$ & $-2.7 \%$ \\
\hline \multicolumn{11}{|l|}{ EU WMP Price } \\
\hline Agenda 2000 & 249 & 251 & 253 & 256 & 252 & 250 & 246 & 250 & 253 & 256 \\
\hline Enlargement & 249 & 251 & 247 & 244 & 240 & 238 & 236 & 240 & 244 & 247 \\
\hline \% Change & $0.0 \%$ & $0.0 \%$ & $-2.4 \%$ & $-4.4 \%$ & $-4.8 \%$ & $-4.7 \%$ & $-4.3 \%$ & $-3.9 \%$ & $-3.6 \%$ & $-3.5 \%$ \\
\hline \multicolumn{5}{|c|}{ Cheese, FOB N.Eur. } & \multicolumn{6}{|c|}{ (U.S. Dollars/MT) } \\
\hline Agenda 2000 & 2,430 & 2,431 & 2,432 & 2,450 & 2,447 & 2,444 & 2,451 & 2,446 & 2,458 & 2,520 \\
\hline Enlargement & 2,430 & 2,431 & 2,457 & 2,435 & 2,428 & 2,427 & 2,446 & 2,454 & 2,469 & 2,514 \\
\hline$\%$ Change & $0.0 \%$ & $0.0 \%$ & $1.0 \%$ & $-0.6 \%$ & $-0.8 \%$ & $-0.7 \%$ & $-0.2 \%$ & $0.3 \%$ & $0.4 \%$ & $-0.3 \%$ \\
\hline \multicolumn{11}{|c|}{ Butter, FOB N.Eur. } \\
\hline Agenda 2000 & 1,746 & 1,765 & 1,791 & 1,815 & 1,864 & 1,888 & 1,890 & 1,887 & 1,884 & 1,870 \\
\hline Enlargement & 1,746 & 1,765 & 1,789 & 1,799 & 1,844 & 1,878 & 1,884 & 1,884 & 1,881 & 1,862 \\
\hline$\%$ Change & $0.0 \%$ & $0.0 \%$ & $-0.2 \%$ & $-0.9 \%$ & $-1.0 \%$ & $-0.5 \%$ & $-0.3 \%$ & $-0.1 \%$ & $-0.2 \%$ & $-0.4 \%$ \\
\hline
\end{tabular}


Impacts of EU enlargement on EU dairy prices (cont.)

\begin{tabular}{|c|c|c|c|c|c|c|c|c|c|c|}
\hline & 2001 & 2002 & 2003 & 2004 & 2005 & 2006 & 2007 & 2008 & 2009 & 2010 \\
\hline \multicolumn{11}{|l|}{ SMP, FOB N.Eur. } \\
\hline Agenda 2000 & 1,418 & 1,460 & 1,475 & 1,501 & 1,509 & 1,557 & 1,657 & 1,711 & 1,749 & 1,793 \\
\hline Enlargement & 1,418 & 1,460 & 1,520 & 1,525 & 1,525 & 1,544 & 1,642 & 1,698 & 1,736 & 1,776 \\
\hline$\%$ Change & $0.0 \%$ & $0.0 \%$ & $3.0 \%$ & $1.6 \%$ & $1.0 \%$ & $-0.9 \%$ & $-0.9 \%$ & $-0.7 \%$ & $-0.7 \%$ & $-1.0 \%$ \\
\hline \multicolumn{11}{|l|}{ WMP, FOB N.Eur. } \\
\hline Agenda 2000 & 1,703 & 1,711 & 1,710 & 1,715 & 1,711 & 1,725 & 1,761 & 1,775 & 1,781 & 1,779 \\
\hline Enlargement & 1,703 & 1,711 & 1,730 & 1,719 & 1,709 & 1,709 & 1,746 & 1,763 & 1,769 & 1,762 \\
\hline$\%$ Change & $0.0 \%$ & $0.0 \%$ & $1.2 \%$ & $0.2 \%$ & $-0.2 \%$ & $-0.9 \%$ & $-0.9 \%$ & $-0.7 \%$ & $-0.7 \%$ & $-1.0 \%$ \\
\hline
\end{tabular}


Impacts of EU enlargement on Czech Republic milk

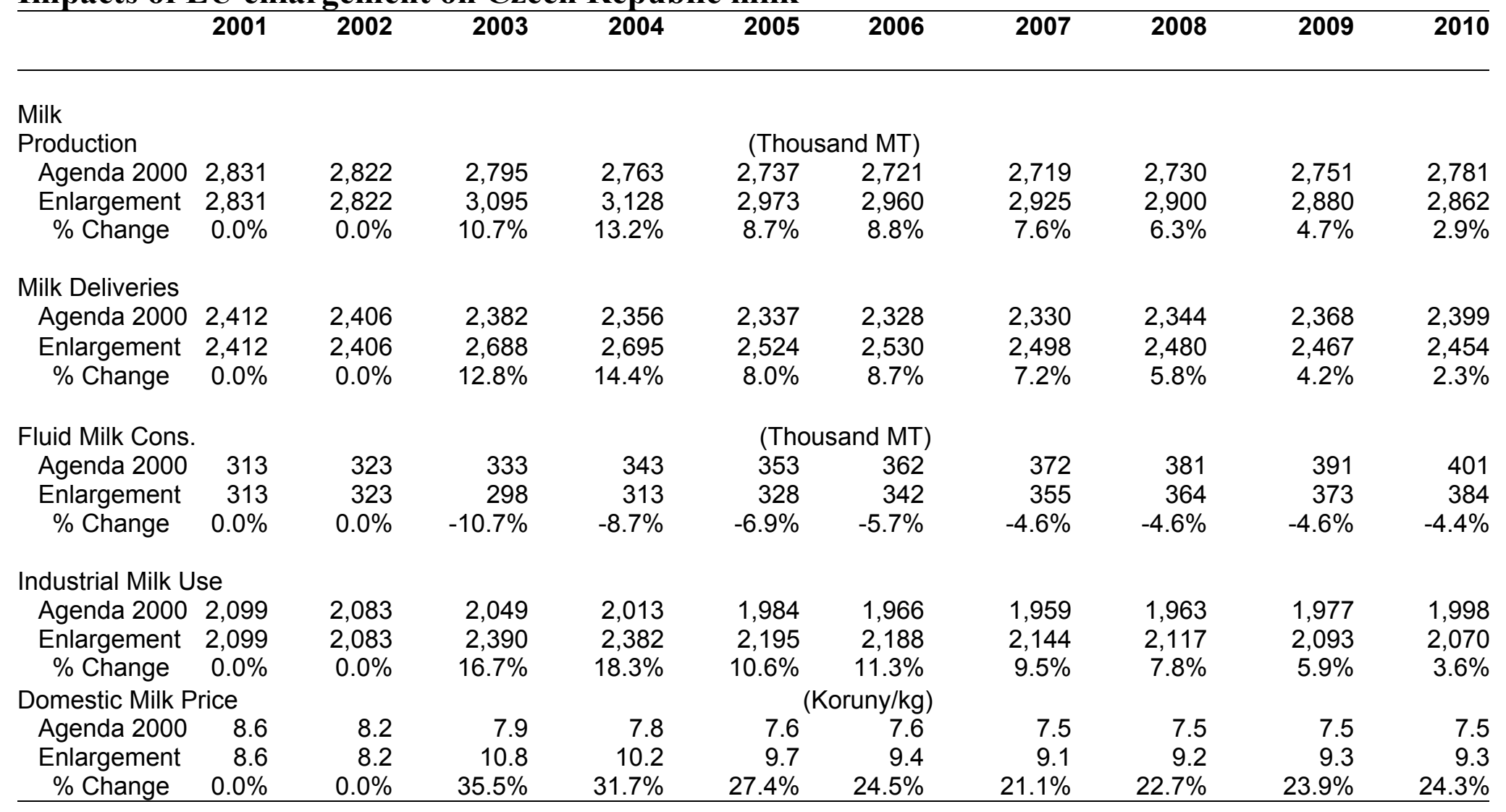


Impacts of EU enlargement on Czech Republic butter

\begin{tabular}{|c|c|c|c|c|c|c|c|c|c|c|}
\hline & 2001 & 2002 & 2003 & 2004 & 2005 & 2006 & 2007 & 2008 & 2009 & 2010 \\
\hline \multicolumn{5}{|c|}{ Butter Production } & \multicolumn{3}{|c|}{ (Thousand MT) } & & & \\
\hline Agenda 2000 & 70 & 69 & 68 & 66 & 65 & 64 & 64 & 63 & 63 & 62 \\
\hline Enlargement & 70 & 69 & 74 & 73 & 68 & 67 & 65 & 64 & 63 & 62 \\
\hline$\%$ Change & $0.0 \%$ & $0.0 \%$ & $8.7 \%$ & $9.2 \%$ & $4.4 \%$ & $4.3 \%$ & $2.8 \%$ & $1.7 \%$ & $0.6 \%$ & $-0.5 \%$ \\
\hline \multicolumn{11}{|c|}{ Butter Consumption } \\
\hline Agenda 2000 & 48 & 48 & 49 & 49 & 49 & 49 & 50 & 50 & 50 & 51 \\
\hline Enlargement & 48 & 48 & 47 & 47 & 48 & 48 & 49 & 49 & 49 & 50 \\
\hline$\%$ Change & $0.0 \%$ & $0.0 \%$ & $-4.2 \%$ & $-3.6 \%$ & $-2.8 \%$ & $-2.4 \%$ & $-2.0 \%$ & $-2.0 \%$ & $-2.0 \%$ & $-2.0 \%$ \\
\hline \multicolumn{11}{|l|}{ Butter Stocks } \\
\hline Agenda 2000 & 2 & 2 & 2 & 2 & 2 & 2 & 2 & 2 & 2 & 2 \\
\hline Enlargement & 2 & 2 & 7 & 8 & 6 & 5 & 4 & 3 & 3 & 2 \\
\hline \% Change & $0.0 \%$ & $0.0 \%$ & $250.1 \%$ & $301.0 \%$ & $220.1 \%$ & $160.9 \%$ & $103.1 \%$ & $58.4 \%$ & $30.9 \%$ & $9.9 \%$ \\
\hline \multicolumn{11}{|c|}{ Butter Net Exports (Excl. EU-18) } \\
\hline Agenda 2000 & 21 & 20 & 19 & 18 & 16 & 15 & 14 & 13 & 12 & 11 \\
\hline Enlargement & 21 & 20 & 12 & 12 & 13 & 14 & 14 & 14 & 13 & 12 \\
\hline$\%$ Change & $0.0 \%$ & $0.0 \%$ & $-36.1 \%$ & $-28.9 \%$ & $-17.6 \%$ & $-7.5 \%$ & $0.5 \%$ & $7.5 \%$ & $8.5 \%$ & $9.2 \%$ \\
\hline \multicolumn{11}{|c|}{ Butter Net Exports to EU-18 } \\
\hline Agenda 2000 & 1 & 1 & 1 & 1 & 1 & 1 & 1 & 1 & 1 & 1 \\
\hline Enlargement & 1 & 1 & 10 & 12 & 9 & 6 & 4 & 2 & 1 & 0 \\
\hline \% Change & $0.0 \%$ & $0.0 \%$ & $752.6 \%$ & $1025.2 \%$ & $788.3 \%$ & $587.7 \%$ & $353.0 \%$ & $152.4 \%$ & $17.7 \%$ & $-96.4 \%$ \\
\hline \multicolumn{5}{|c|}{ Domestic Butter Price } & \multicolumn{3}{|c|}{ (Koruny/kg) } & & & \\
\hline Agenda 2000 & 85.6 & 82.1 & 80.0 & 78.4 & 78.5 & 77.9 & 76.7 & 76.0 & 75.4 & 74.3 \\
\hline Enlargement & 85.6 & 82.1 & 135.0 & 127.7 & 118.9 & 113.3 & 108.2 & 108.9 & 109.2 & 109.1 \\
\hline$\%$ Change & $0.0 \%$ & $0.0 \%$ & $68.8 \%$ & $62.8 \%$ & $51.5 \%$ & $45.5 \%$ & $40.9 \%$ & $43.3 \%$ & $44.9 \%$ & $46.9 \%$ \\
\hline
\end{tabular}


Impacts of EU enlargement on Czech Republic cheese

\begin{tabular}{|c|c|c|c|c|c|c|c|c|c|c|}
\hline & 2001 & 2002 & 2003 & 2004 & 2005 & 2006 & 2007 & 2008 & 2009 & 2010 \\
\hline \multicolumn{5}{|c|}{ Cheese Production } & \multicolumn{2}{|c|}{ (Thousand MT) } & & & & \\
\hline Agenda 2000 & 80 & 80 & 79 & 78 & 77 & 76 & 76 & 76 & 77 & 78 \\
\hline Enlargement & 80 & 80 & 99 & 99 & 90 & 91 & 89 & 89 & 88 & 87 \\
\hline$\%$ Change & $0.0 \%$ & $0.0 \%$ & $25.7 \%$ & $27.2 \%$ & $17.7 \%$ & $19.7 \%$ & $18.4 \%$ & $16.7 \%$ & $14.5 \%$ & $11.5 \%$ \\
\hline \multicolumn{11}{|c|}{ Cheese Consumption } \\
\hline Agenda 2000 & 77 & 79 & 80 & 81 & 83 & 84 & 85 & 86 & 87 & 88 \\
\hline Enlargement & 77 & 79 & 74 & 76 & 78 & 79 & 81 & 82 & 83 & 84 \\
\hline$\%$ Change & $0.0 \%$ & $0.0 \%$ & $-7.8 \%$ & $-6.9 \%$ & $-6.2 \%$ & $-5.7 \%$ & $-5.2 \%$ & $-5.1 \%$ & $-5.0 \%$ & $-4.7 \%$ \\
\hline \multicolumn{11}{|l|}{ Cheese Stocks } \\
\hline Agenda 2000 & 3 & 3 & 3 & 3 & 3 & 3 & 3 & 3 & 3 & 3 \\
\hline Enlargement & 3 & 3 & 15 & 19 & 16 & 15 & 14 & 13 & 12 & 11 \\
\hline$\%$ Change & $0.0 \%$ & $0.0 \%$ & $415.4 \%$ & $527.4 \%$ & $448.7 \%$ & $413.2 \%$ & $366.6 \%$ & $333.8 \%$ & $305.9 \%$ & $275.2 \%$ \\
\hline \multicolumn{11}{|c|}{ Cheese Net Exports (Excl. EU-18) } \\
\hline Agenda 2000 & -4 & -4 & -1 & -4 & -6 & -8 & -9 & -10 & -10 & -10 \\
\hline Enlargement & -4 & -4 & -17 & -17 & -17 & -17 & -17 & -17 & -17 & -17 \\
\hline$\%$ Change & $0.0 \%$ & $0.0 \%$ & $1139.2 \%$ & $341.6 \%$ & $175.9 \%$ & $109.8 \%$ & $74.6 \%$ & $65.5 \%$ & $65.3 \%$ & $72.3 \%$ \\
\hline \multicolumn{11}{|c|}{ Cheese Net Exports to EU-18 } \\
\hline Agenda 2000 & 7 & 5 & 2 & 0 & -2 & -4 & -6 & -7 & -7 & -6 \\
\hline Enlargement & 7 & 5 & 30 & 36 & 32 & 30 & 27 & 25 & 23 & 21 \\
\hline$\%$ Change & $0.0 \%$ & $0.0 \%$ & $1246.2 \%$ & $-15196.2 \%$ & $-1371.3 \%$ & $-773.5 \%$ & $-555.3 \%$ & $-473.2 \%$ & $-437.1 \%$ & $-429.9 \%$ \\
\hline \multicolumn{5}{|c|}{ Domestic Cheese Price } & \multicolumn{2}{|c|}{ (Koruny/kg) } & & & & \\
\hline Agenda 2000 & 102.1 & 95.7 & 91.0 & 87.9 & 85.2 & 82.9 & 81.5 & 80.5 & 80.1 & 81.1 \\
\hline Enlargement & 102.1 & 95.7 & 177.5 & 168.9 & 162.4 & 157.9 & 154.3 & 155.7 & 156.8 & 157.8 \\
\hline$\%$ Change & $0.0 \%$ & $0.0 \%$ & $95.1 \%$ & $92.1 \%$ & $90.7 \%$ & $90.4 \%$ & $89.3 \%$ & $93.3 \%$ & $95.8 \%$ & $94.5 \%$ \\
\hline
\end{tabular}


Impacts of EU enlargement on Czech Republic skim milk powder

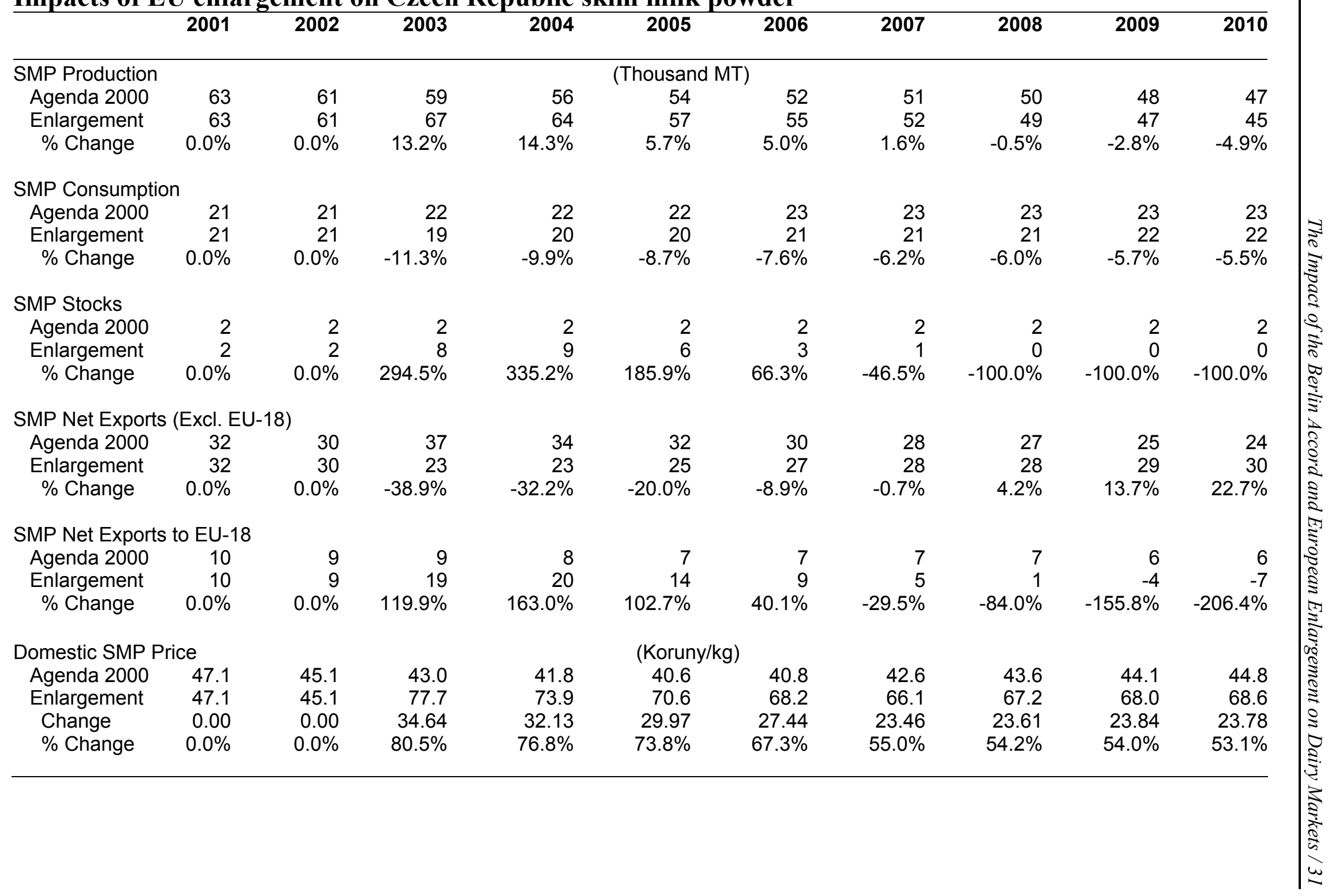




\section{Impacts of EU enlargement on Hungary milk}

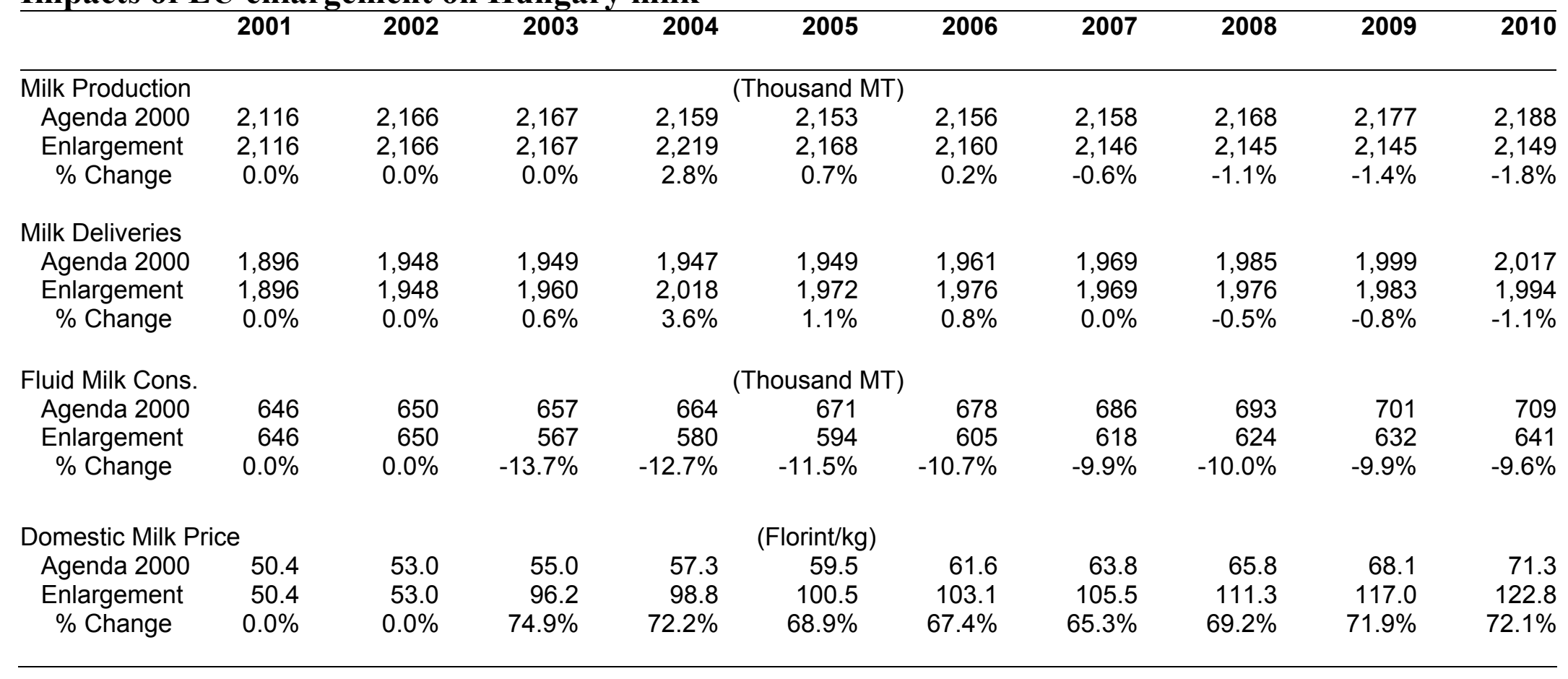




\section{Impacts of EU enlargement on Hungary butter}

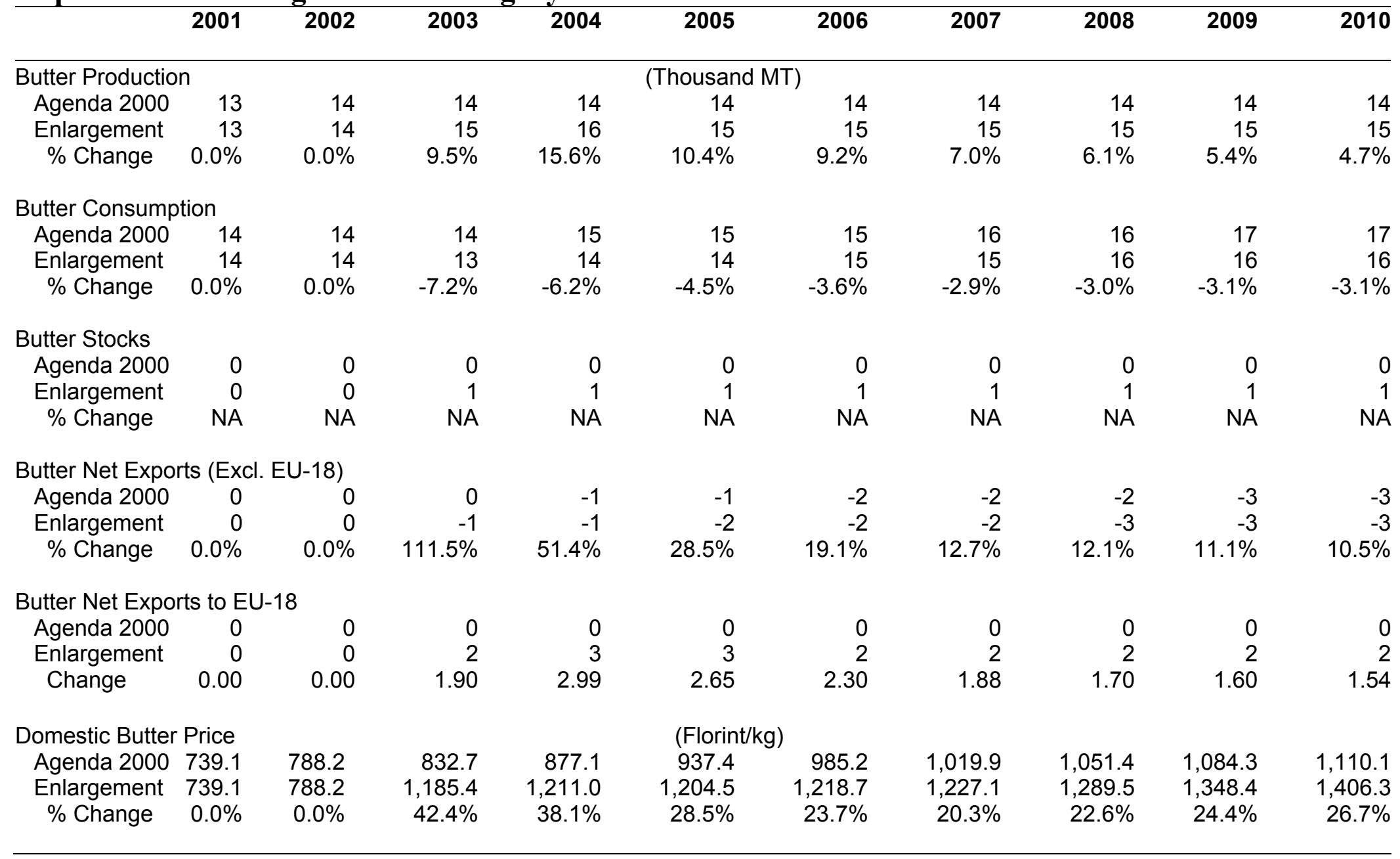




\section{Impacts of EU enlargement on Hungary cheese}

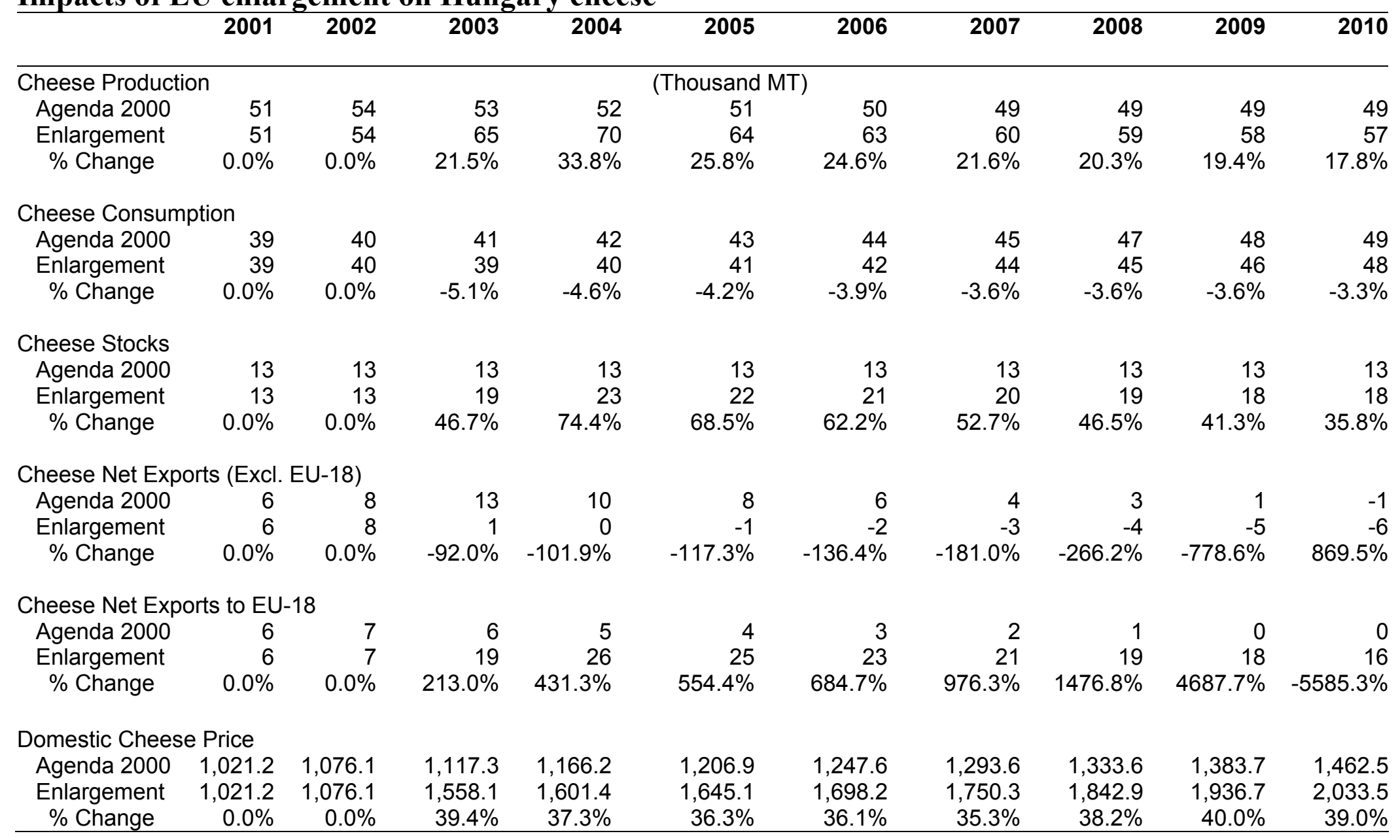


Impacts of EU enlargement on Hungary skim milk powder

\begin{tabular}{|c|c|c|c|c|c|c|c|c|c|c|}
\hline & 2001 & 2002 & 2003 & 2004 & 2005 & 2006 & 2007 & 2008 & 2009 & 2010 \\
\hline SMP Production & \multicolumn{10}{|c|}{ (Thousand Metric Tons) } \\
\hline Agenda 2000 & 10 & 10 & 10 & 10 & 10 & 10 & 10 & 10 & 10 & 11 \\
\hline Enlargement & 10 & 10 & 11 & 11 & 11 & 11 & 10 & 10 & 10 & 10 \\
\hline$\%$ Change & $0.0 \%$ & $0.0 \%$ & $8.7 \%$ & $12.5 \%$ & $6.9 \%$ & $4.8 \%$ & $1.9 \%$ & $0.9 \%$ & $0.2 \%$ & $-0.1 \%$ \\
\hline \multicolumn{11}{|c|}{ SMP Consumption } \\
\hline Agenda 2000 & 9 & 9 & 9 & 10 & 10 & 10 & 10 & 10 & 10 & 10 \\
\hline Enlargement & 9 & 9 & 9 & 9 & 9 & 10 & 10 & 10 & 10 & 10 \\
\hline \% Change & $0.0 \%$ & $0.0 \%$ & $-2.1 \%$ & $-1.9 \%$ & $-1.7 \%$ & $-1.4 \%$ & $-1.0 \%$ & $-1.0 \%$ & $-1.0 \%$ & $-0.9 \%$ \\
\hline \multicolumn{11}{|l|}{ SMP Stocks } \\
\hline Agenda 2000 & 0 & 0 & 0 & 0 & 0 & 0 & 0 & 0 & 0 & 0 \\
\hline Enlargement & 0 & 0 & 0 & 1 & 1 & 0 & 0 & 0 & 0 & 0 \\
\hline$\%$ Change & NA & NA & NA & NA & NA & NA & NA & NA & NA & NA \\
\hline \multicolumn{11}{|c|}{ SMP Net Exports (Excl. EU-18) } \\
\hline Agenda 2000 & 0 & 1 & 1 & 1 & 0 & 0 & 1 & 1 & 1 & 0 \\
\hline Enlargement & 0 & 1 & 0 & 0 & 0 & 0 & 0 & 0 & 0 & 0 \\
\hline$\%$ Change & $0.0 \%$ & $0.0 \%$ & $-39.2 \%$ & $-46.8 \%$ & $-52.6 \%$ & $-48.8 \%$ & $-41.5 \%$ & $-39.4 \%$ & $-42.4 \%$ & $-49.6 \%$ \\
\hline \multicolumn{11}{|c|}{ SMP Net Exports to EU-18 } \\
\hline Agenda 2000 & 0 & 0 & 0 & 0 & 0 & 0 & 0 & 0 & 0 & 0 \\
\hline Enlargement & 0 & 0 & 1 & 1 & 1 & 1 & 1 & 0 & 0 & 0 \\
\hline$\%$ Change & NA & NA & NA & NA & NA & NA & NA & NA & NA & NA \\
\hline Domestic SMP & \multicolumn{10}{|c|}{ (Florint/kq) } \\
\hline Agenda 2000 & 420.4 & 455.0 & 476.8 & 502.5 & 523.2 & 557.6 & 611.2 & 650.6 & 686.2 & 725.5 \\
\hline Enlargement & 420.4 & 455.0 & 681.7 & 701.2 & 714.8 & 733.6 & 749.6 & 795.6 & 839.7 & 884.0 \\
\hline$\%$ Change & $0.0 \%$ & $0.0 \%$ & $43.0 \%$ & $39.5 \%$ & $36.6 \%$ & $31.6 \%$ & $22.6 \%$ & $22.3 \%$ & $22.4 \%$ & $21.8 \%$ \\
\hline
\end{tabular}


Impacts of EU enlargement on Poland milk

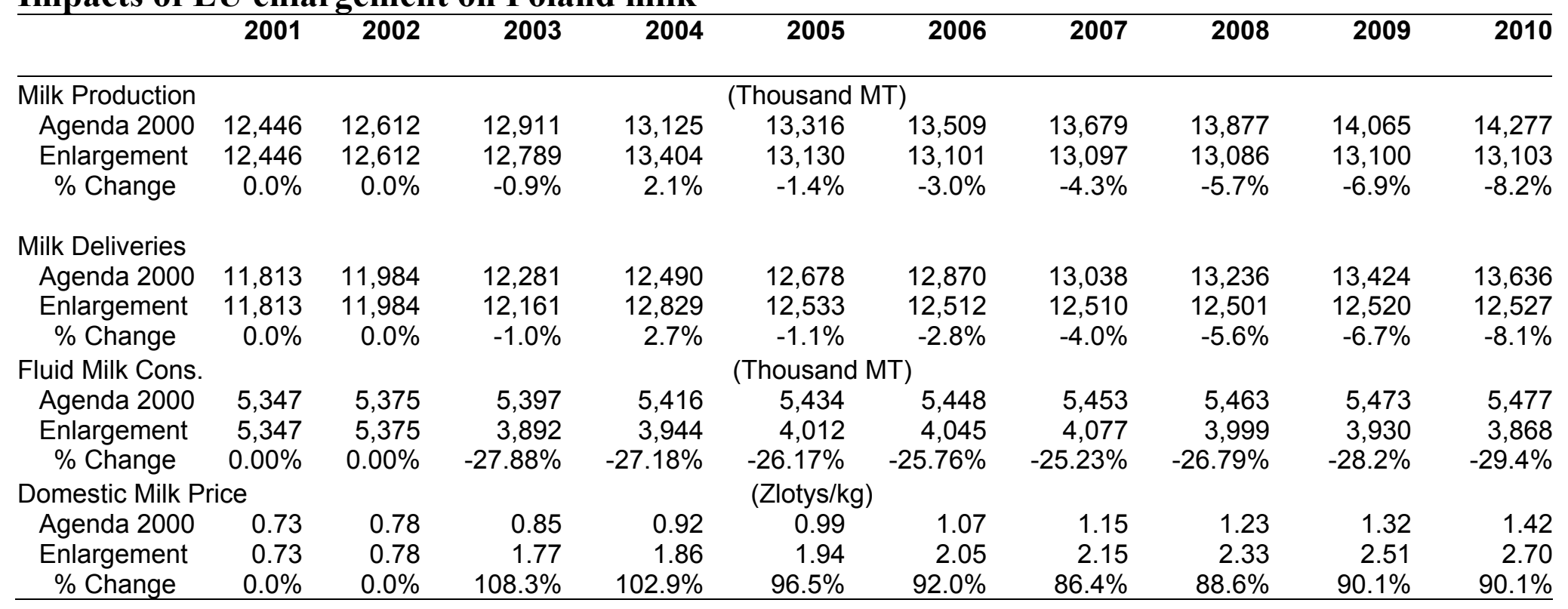




\section{Impacts of EU enlargement on Poland butter}

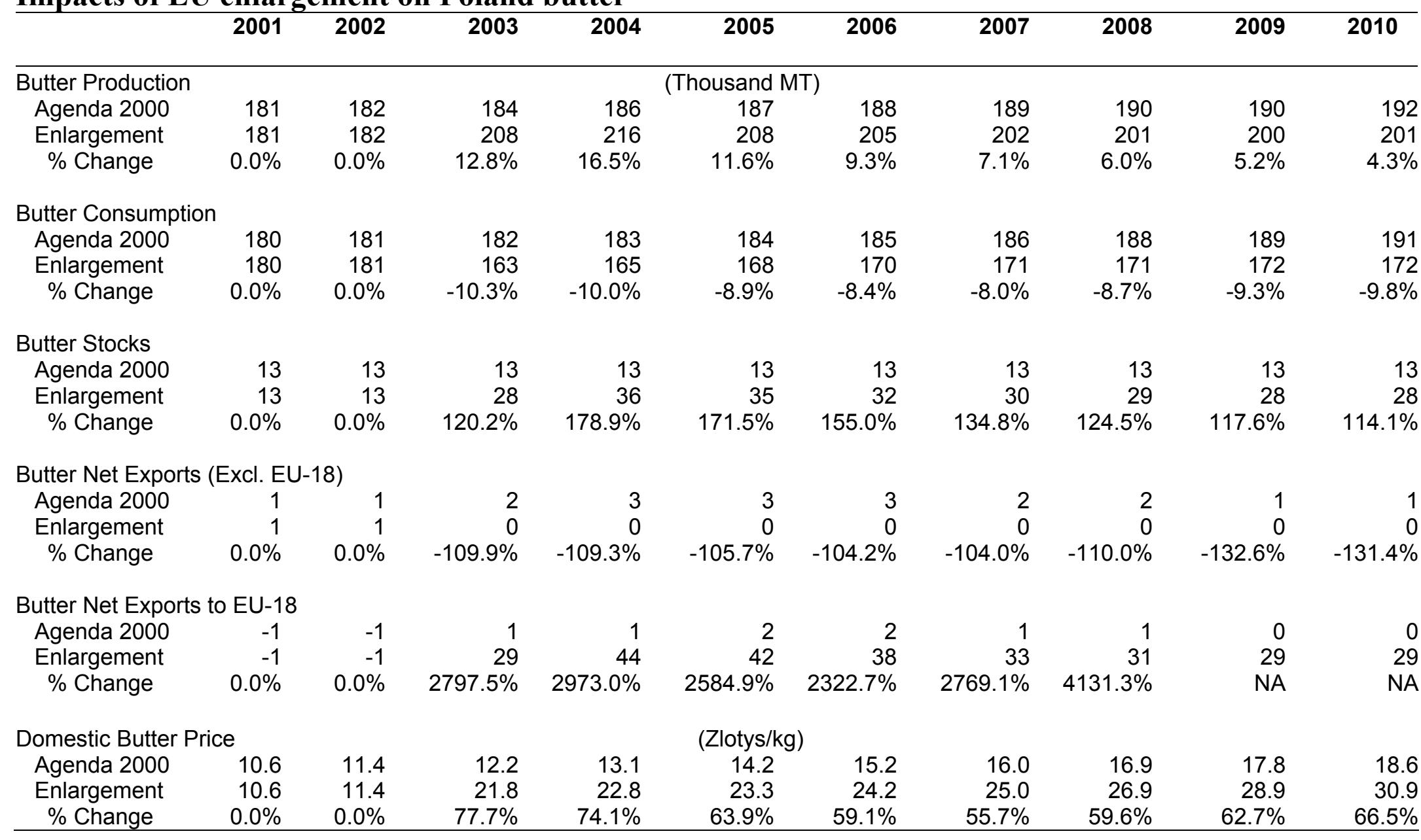


Impacts of EU enlargement on Poland cheese

\begin{tabular}{|c|c|c|c|c|c|c|c|c|c|c|}
\hline & 2001 & 2002 & 2003 & 2004 & 2005 & 2006 & 2007 & 2008 & 2009 & 2010 \\
\hline \multicolumn{5}{|c|}{ Cheese Production } & \multicolumn{6}{|c|}{ (Thousand MT) } \\
\hline Agenda 2000 & 188 & 189 & 195 & 198 & 200 & 201 & 202 & 204 & 205 & 207 \\
\hline Enlargement & 188 & 189 & 335 & 369 & 344 & 336 & 329 & 331 & 333 & 333 \\
\hline$\%$ Change & $0.0 \%$ & $0.0 \%$ & $71.7 \%$ & $86.9 \%$ & $72.5 \%$ & $67.2 \%$ & $63.2 \%$ & $62.5 \%$ & $62.7 \%$ & $61.0 \%$ \\
\hline \multicolumn{11}{|c|}{ Cheese Consumption } \\
\hline Agenda 2000 & 165 & 167 & 170 & 172 & 175 & 178 & 181 & 184 & 187 & 190 \\
\hline Enlargement & 165 & 167 & 160 & 163 & 166 & 169 & 171 & 174 & 176 & 178 \\
\hline$\%$ Change & $0.0 \%$ & $0.0 \%$ & $-5.7 \%$ & $-5.5 \%$ & $-5.3 \%$ & $-5.3 \%$ & $-5.3 \%$ & $-5.7 \%$ & $-6.0 \%$ & $-6.1 \%$ \\
\hline \multicolumn{11}{|l|}{ Cheese Stocks } \\
\hline Agenda 2000 & 17 & 17 & 18 & 18 & 18 & 19 & 19 & 19 & 19 & 19 \\
\hline Enlargement & 17 & 17 & 68 & 96 & 96 & 93 & 88 & 87 & 86 & 85 \\
\hline$\%$ Change & $0.0 \%$ & $0.0 \%$ & $285.2 \%$ & $431.8 \%$ & $422.0 \%$ & $394.9 \%$ & $365.7 \%$ & $351.0 \%$ & $344.1 \%$ & $338.7 \%$ \\
\hline \multicolumn{11}{|c|}{ Cheese Net Exports (Excl. EU-18) } \\
\hline Agenda 2000 & 15 & 15 & 25 & 25 & 24 & 23 & 20 & 19 & 18 & 17 \\
\hline Enlargement & 15 & 15 & 7 & 7 & 6 & 6 & 6 & 6 & 6 & 5 \\
\hline$\%$ Change & $0.0 \%$ & $0.0 \%$ & $-73.3 \%$ & $-73.6 \%$ & $-72.9 \%$ & $-72.0 \%$ & $-69.1 \%$ & $-69.2 \%$ & $-68.2 \%$ & $-68.3 \%$ \\
\hline \multicolumn{11}{|c|}{ Cheese Net Exports to EU-18 } \\
\hline Agenda 2000 & 8 & 6 & 10 & 10 & 9 & 8 & 5 & 4 & 3 & 3 \\
\hline Enlargement & 8 & 6 & 118 & 172 & 172 & 165 & 156 & 153 & 152 & 151 \\
\hline$\%$ Change & $0.0 \%$ & $0.0 \%$ & $1101.0 \%$ & $1690.9 \%$ & $1853.1 \%$ & $2045.1 \%$ & $2740.6 \%$ & $3341.1 \%$ & $5016.5 \%$ & $5814.2 \%$ \\
\hline \multicolumn{5}{|c|}{ Domestic Cheese Price } & \multicolumn{2}{|c|}{ (Zlotys/kg) } & & & & \\
\hline Agenda 2000 & 15.9 & 17.0 & 18.2 & 19.5 & 20.7 & 21.9 & 23.3 & 24.7 & 26.2 & 28.4 \\
\hline Enlargement & 15.9 & 17.0 & 28.6 & 30.2 & 31.8 & 33.7 & 35.6 & 38.5 & 41.5 & 44.7 \\
\hline$\%$ Change & $0.0 \%$ & $0.0 \%$ & $57.5 \%$ & $55.1 \%$ & $54.0 \%$ & $53.8 \%$ & $52.8 \%$ & $56.1 \%$ & $58.1 \%$ & $57.1 \%$ \\
\hline
\end{tabular}




\section{Impacts of EU enlargement on Poland skim milk powder}

\begin{tabular}{|c|c|c|c|c|c|c|c|c|c|c|}
\hline & 2001 & 2002 & 2003 & 2004 & 2005 & 2006 & 2007 & 2008 & 2009 & 2010 \\
\hline SMP Production & \multicolumn{10}{|c|}{ (Thousand Metric Tons) } \\
\hline Agenda 2000 & 122 & 125 & 131 & 135 & 138 & 141 & 145 & 148 & 151 & 155 \\
\hline Enlargement & 122 & 125 & 158 & 169 & 160 & 157 & 154 & 154 & 154 & 156 \\
\hline$\%$ Change & $0.0 \%$ & $0.0 \%$ & $20.8 \%$ & $25.5 \%$ & $16.1 \%$ & $11.1 \%$ & $6.4 \%$ & $3.9 \%$ & $2.2 \%$ & $0.5 \%$ \\
\hline \multicolumn{11}{|c|}{ SMP Consumption } \\
\hline Agenda 2000 & 27 & 28 & 28 & 29 & 29 & 30 & 30 & 31 & 31 & 32 \\
\hline Enlargement & 27 & 28 & 26 & 27 & 28 & 28 & 29 & 30 & 30 & 31 \\
\hline$\%$ Change & $0.0 \%$ & $0.0 \%$ & $-7.7 \%$ & $-6.8 \%$ & $-6.0 \%$ & $-5.0 \%$ & $-3.2 \%$ & $-2.9 \%$ & $-2.7 \%$ & $-2.4 \%$ \\
\hline \multicolumn{11}{|l|}{ SMP Stocks } \\
\hline Agenda 2000 & 15 & 15 & 15 & 15 & 15 & 15 & 15 & 14 & 14 & 14 \\
\hline Enlargement & 15 & 15 & 32 & 41 & 40 & 38 & 35 & 33 & 32 & 32 \\
\hline$\%$ Change & $0.0 \%$ & $0.0 \%$ & $116.1 \%$ & $175.8 \%$ & $169.8 \%$ & $156.2 \%$ & $137.7 \%$ & $128.5 \%$ & $123.4 \%$ & $122.3 \%$ \\
\hline \multicolumn{11}{|c|}{ SMP Net Exports (Excl. EU-18) } \\
\hline Agenda 2000 & 69 & 68 & 103 & 106 & 108 & 112 & 115 & 118 & 120 & 123 \\
\hline Enlargement & 69 & 68 & 51 & 53 & 54 & 56 & 60 & 61 & 61 & 62 \\
\hline$\%$ Change & $0.0 \%$ & $0.0 \%$ & $-50.4 \%$ & $-50.4 \%$ & $-50.0 \%$ & $-49.7 \%$ & $-48.3 \%$ & $-48.7 \%$ & $-49.0 \%$ & $-49.8 \%$ \\
\hline \multicolumn{11}{|c|}{ SMP Net Exports to EU-18 } \\
\hline Agenda 2000 & 26 & 29 & 34 & 37 & 39 & 41 & 44 & 46 & 48 & 51 \\
\hline Enlargement & 26 & 29 & 64 & 81 & 79 & 75 & 69 & 66 & 64 & 63 \\
\hline$\%$ Change & $0.0 \%$ & $0.0 \%$ & $88.5 \%$ & $120.5 \%$ & $105.0 \%$ & $81.8 \%$ & $56.5 \%$ & $41.6 \%$ & $32.7 \%$ & $23.7 \%$ \\
\hline \multicolumn{6}{|c|}{ Domestic SMP Price } & \multicolumn{5}{|l|}{ (Zlotys $/ \mathrm{kg}$ ) } \\
\hline Agenda 2000 & 7.1 & 7.6 & 8.4 & 9.3 & 10.2 & 11.4 & 13.1 & 14.6 & 16.0 & 17.5 \\
\hline Enlargement & \#N/A & \#N/A & $\# N / A$ & \#N/A & \#N/A & $\# \mathrm{~N} / \mathrm{A}$ & $\# N / A$ & $\# \mathrm{~N} / \mathrm{A}$ & $\# N / A$ & $\# \mathrm{~N} / \mathrm{A}$ \\
\hline
\end{tabular}


Impacts of EU enlargement on world cheese markets

\begin{tabular}{|c|c|c|c|c|c|c|c|c|c|c|}
\hline & 2001 & 2002 & 2003 & 2004 & 2005 & 2006 & 2007 & 2008 & 2009 & 2010 \\
\hline \multicolumn{11}{|c|}{ EU Net Exports $\quad$ (Thousand MT) } \\
\hline Agenda 2000 & 309 & 312 & 314 & 317 & 324 & 331 & 341 & 340 & 342 & 350 \\
\hline Enlargement & 309 & 312 & 350 & 365 & 378 & 389 & 402 & 405 & 406 & 407 \\
\hline$\%$ Change & $0.0 \%$ & $0.0 \%$ & $11.6 \%$ & $15.4 \%$ & $16.8 \%$ & $17.6 \%$ & $18.1 \%$ & $19.1 \%$ & $18.6 \%$ & $16.1 \%$ \\
\hline \multicolumn{11}{|c|}{ New Zealand Net Exports } \\
\hline Agenda 2000 & 244 & 252 & 260 & 271 & 281 & 290 & 298 & 307 & 318 & 343 \\
\hline Enlargement & 244 & 252 & 261 & 269 & 279 & 289 & 298 & 308 & 320 & 344 \\
\hline$\%$ Change & $0.0 \%$ & $0.0 \%$ & $0.2 \%$ & $-0.5 \%$ & $-0.5 \%$ & $-0.1 \%$ & $0.2 \%$ & $0.5 \%$ & $0.5 \%$ & $0.1 \%$ \\
\hline \multicolumn{11}{|c|}{ Australia Net Exports } \\
\hline Agenda 2000 & 138 & 141 & 145 & 150 & 155 & 158 & 158 & 160 & 164 & 171 \\
\hline Enlargement & 138 & 141 & 144 & 148 & 152 & 157 & 159 & 161 & 165 & 172 \\
\hline$\%$ Change & $0.0 \%$ & $0.0 \%$ & $-0.5 \%$ & $-1.5 \%$ & $-1.5 \%$ & $-0.6 \%$ & $0.2 \%$ & $0.8 \%$ & $1.1 \%$ & $0.7 \%$ \\
\hline \multicolumn{11}{|c|}{ Argentina Net Exports } \\
\hline Agenda 2000 & 31 & 33 & 35 & 39 & 40 & 40 & 41 & 41 & 41 & 44 \\
\hline Enlargement & 31 & 33 & 38 & 38 & 39 & 39 & 41 & 42 & 42 & 46 \\
\hline$\%$ Change & $0.0 \%$ & $0.0 \%$ & $7.9 \%$ & $-0.9 \%$ & $-2.9 \%$ & $-3.4 \%$ & $-2.0 \%$ & $0.2 \%$ & $1.3 \%$ & $3.8 \%$ \\
\hline \multicolumn{11}{|c|}{ Russia Net Imports } \\
\hline Agenda 2000 & 261 & 270 & 277 & 286 & 291 & 288 & 285 & 276 & 271 & 289 \\
\hline Enlargement & 261 & 270 & 274 & 281 & 287 & 290 & 298 & 299 & 298 & 311 \\
\hline$\%$ Change & $0.0 \%$ & $0.0 \%$ & $-1.0 \%$ & $-1.9 \%$ & $-1.4 \%$ & $0.6 \%$ & $4.4 \%$ & $8.2 \%$ & $10.0 \%$ & $7.7 \%$ \\
\hline \multicolumn{11}{|c|}{ Japan Net Imports } \\
\hline Agenda 2000 & 204 & 214 & 226 & 238 & 251 & 265 & 279 & 294 & 309 & 324 \\
\hline Enlargement & 204 & 214 & 225 & 238 & 252 & 265 & 279 & 293 & 309 & 324 \\
\hline$\%$ Change & $0.0 \%$ & $0.0 \%$ & $-0.2 \%$ & $0.0 \%$ & $0.2 \%$ & $0.2 \%$ & $0.1 \%$ & $0.0 \%$ & $-0.1 \%$ & $0.0 \%$ \\
\hline \multicolumn{11}{|l|}{ U.S. Net Imports } \\
\hline Agenda 2000 & 117 & 117 & 118 & 118 & 118 & 118 & 119 & 119 & 119 & 119 \\
\hline Enlargement & 117 & 117 & 118 & 118 & 118 & 118 & 119 & 119 & 119 & 119 \\
\hline$\%$ Change & $0.0 \%$ & $0.0 \%$ & $0.0 \%$ & $0.0 \%$ & $0.0 \%$ & $0.0 \%$ & $0.0 \%$ & $0.0 \%$ & $0.0 \%$ & $0.0 \%$ \\
\hline \multicolumn{11}{|c|}{ Rest of World New Imports } \\
\hline Agenda 2000 & 126 & 126 & 124 & 120 & 118 & 119 & 120 & 121 & 118 & 122 \\
\hline Change & 0.00 & 0.00 & -2.58 & 1.20 & 3.09 & 2.92 & 1.22 & -1.14 & -2.51 & -0.77 \\
\hline$\%$ Change & $0.0 \%$ & $0.0 \%$ & $-2.1 \%$ & $1.0 \%$ & $2.6 \%$ & $2.5 \%$ & $1.0 \%$ & $-0.9 \%$ & $-2.1 \%$ & $-0.6 \%$ \\
\hline
\end{tabular}


Impacts of EU enlargement on world butter markets

2001

2002

2003

$2004 \quad 2005$

2006

2007

2008

2009

2010

EU Net Exports

Agenda 2000

Enlargement

137

145

137
$0.0 \%$

145

149

$\%$ Change

$0.0 \%$

152
$2.4 \%$

\section{1}

(Thousand MT)

New Zealand Net Exports

Agenda $2000 \quad 330$

Enlargement $\quad 330$

$334 \quad 336$

$\%$ Change

$0.0 \%$

334

$0.0 \%$

338

$0.6 \%$

158
$4.7 \%$

144
154

132

144
$8.7 \%$

115

127
$10.6 \%$

107

119
$11.4 \%$

105

117

$11.4 \%$

105

$6.5 \%$

$10.5 \%$

Australia Net Exports

Agenda $2000 \quad 105$

108

Enlargement $\quad 105$

$\%$ Change $\quad 0.0 \%$

108

338
340

342

347

353
352

$0.5 \%$

$0.3 \%$

346

$-0.1 \%$

$-0.2 \%$

357
356

360

$-0.2 \%$

$-0.2 \%$

365

$-0.2 \%$

Argentina Net Exports

Agenda $2000 \quad 8$

$\begin{array}{cr}\text { Enlargement } & 8 \\ \% \text { Change } & 0.0 \%\end{array}$

$0.0 \% \quad 0.0 \%$

111

114

118

122

127

131

134

$0.8 \%$

$0.5 \%$

$-0.1 \%$

$-0.3 \%$

130

134

$-0.3 \%$

142
142

$-0.4 \%$

Russia Net Imports

Agenda $2000 \quad 201$

Enlargement $\quad 201$

$\%$ Change $\quad 0.0 \%$

\section{0}

210

9

Ukraine Net Exports

Agenda 2000

Enlargement

51
51

$0.0 \%$

10

10
$8.5 \%$

10
$6.2 \%$

10
11

11

$3.6 \%$

$-1.5 \%$

13
13

$-2.3 \%$

13
13

$-2.6 \%$

13
13

$-2.7 \%$

13

13
$0.2 \%$

$\%$ Change

51
$0.0 \%$

52

215

221

226

228

$-0.2 \%$

$-0.3 \%$

$-0.1 \%$

229
$0.3 \%$

225

228

219

213

224

218

211

$1.1 \%$

$2.0 \%$

$2.3 \%$

$1.9 \%$

U.S. Net Exports

Agenda 2000

Enlargement

$\%$ Change

-4
-4
$0.0 \%$

$0.0 \%$

52

53

53

$0.4 \%$

$0.0 \%$

54
53

54

54

54

$-0.4 \%$

$-0.7 \%$

$-1.1 \%$

$-1.3 \%$

53
52

$-1.5 \%$

52
51

Rest of World Net Imports

Agenda $2000 \quad 363$

Enlargement $\quad 363$

$\%$ Change $\quad 0.0 \%$

-5
-5
$0.0 \%$

-2
-2

0
0

$0.0 \%$

1
1
$0.0 \%$

3
3

$0.0 \%$

$0.0 \%$

5
5

6

$0.0 \%$

$0.0 \%$

$\begin{array}{rr}7 & 14 \\ 7 & 14\end{array}$

365

365

$0.0 \%$

363
363
$0.1 \%$

360

351

345

345
349

345

363
$0.8 \%$

355
$1.3 \%$

$1.1 \%$

348
$0.8 \%$

349

$0.0 \%$

$0.0 \%$

351
$0.5 \%$

355

356

367

369

$0.6 \%$ 
Impacts of EU enlargement on world SMP markets

\begin{tabular}{|c|c|c|c|c|c|c|c|c|c|c|}
\hline & 2001 & 2002 & 2003 & 2004 & 2005 & 2006 & 2007 & 2008 & 2009 & 2010 \\
\hline EU Net Exports & \multicolumn{10}{|c|}{ (Thousand MT) } \\
\hline Agenda 2000 & 194 & 194 & 194 & 194 & 194 & 177 & 135 & 116 & 108 & 103 \\
\hline Enlargement & 194 & 194 & 237 & 239 & 240 & 237 & 196 & 178 & 169 & 165 \\
\hline \% Change & $0.0 \%$ & $0.0 \%$ & $22.0 \%$ & $23.2 \%$ & $23.8 \%$ & $33.8 \%$ & $45.4 \%$ & $53.5 \%$ & $57.3 \%$ & $60.8 \%$ \\
\hline \multicolumn{11}{|c|}{ New Zealand Net Exports } \\
\hline Agenda 2000 & 236 & 247 & 255 & 264 & 273 & 286 & 301 & 313 & 321 & 332 \\
\hline Enlargement & 236 & 247 & 259 & 267 & 276 & 286 & 300 & 311 & 320 & 331 \\
\hline$\%$ Change & $0.0 \%$ & $0.0 \%$ & $1.3 \%$ & $1.2 \%$ & $0.8 \%$ & $-0.1 \%$ & $-0.4 \%$ & $-0.5 \%$ & $-0.6 \%$ & $-0.4 \%$ \\
\hline \multicolumn{11}{|c|}{ Australia Net Exports } \\
\hline Agenda 2000 & 206 & 215 & 224 & 233 & 242 & 253 & 267 & 278 & 288 & 306 \\
\hline Enlargement & 206 & 215 & 227 & 235 & 244 & 253 & 266 & 277 & 287 & 304 \\
\hline$\%$ Change & $0.0 \%$ & $0.0 \%$ & $1.5 \%$ & $1.1 \%$ & $0.8 \%$ & $-0.1 \%$ & $-0.3 \%$ & $-0.4 \%$ & $-0.4 \%$ & $-0.4 \%$ \\
\hline \multicolumn{11}{|c|}{ Mexico Net Imports } \\
\hline Agenda 2000 & 130 & 131 & 135 & 138 & 143 & 146 & 148 & 151 & 156 & 161 \\
\hline Enlargement & 130 & 131 & 133 & 137 & 142 & 146 & 148 & 152 & 156 & 162 \\
\hline$\%$ Change & $0.0 \%$ & $0.0 \%$ & $-1.4 \%$ & $-0.8 \%$ & $-0.4 \%$ & $0.4 \%$ & $0.5 \%$ & $0.4 \%$ & $0.4 \%$ & $0.5 \%$ \\
\hline \multicolumn{11}{|c|}{ Brazil Net Imports } \\
\hline Agenda 2000 & 43 & 42 & 43 & 45 & 47 & 48 & 46 & 48 & 53 & 59 \\
\hline Enlargement & 43 & 42 & 41 & 43 & 45 & 48 & 47 & 49 & 54 & 59 \\
\hline$\%$ Change & $0.0 \%$ & $0.0 \%$ & $-6.0 \%$ & $-5.2 \%$ & $-3.8 \%$ & $0.1 \%$ & $1.1 \%$ & $1.6 \%$ & $1.7 \%$ & $0.0 \%$ \\
\hline \multicolumn{11}{|l|}{ U.S. Net Exports } \\
\hline Agenda 2000 & 88 & 69 & 68 & 68 & 68 & 67 & 67 & 67 & 67 & 56 \\
\hline Enlargement & 88 & 69 & 68 & 68 & 68 & 67 & 67 & 67 & 67 & 56 \\
\hline$\%$ Change & $0.0 \%$ & $0.0 \%$ & $0.0 \%$ & $0.0 \%$ & $0.0 \%$ & $0.0 \%$ & $0.0 \%$ & $0.0 \%$ & $0.0 \%$ & $0.0 \%$ \\
\hline \multicolumn{11}{|c|}{ Rest of World Net Imports } \\
\hline Agenda 2000 & 72 & 68 & 69 & 70 & 70 & 68 & 61 & 55 & 50 & 49 \\
\hline Enlargement & 72 & 68 & 66 & 66 & 67 & 68 & 61 & 56 & 51 & 50 \\
\hline$\%$ Change & $0.0 \%$ & $0.0 \%$ & $-4.8 \%$ & $-4.8 \%$ & $-3.9 \%$ & $-0.5 \%$ & $1.2 \%$ & $1.9 \%$ & $2.4 \%$ & $3.0 \%$ \\
\hline
\end{tabular}


Impacts of EU enlargement on world WMP markets

\begin{tabular}{|c|c|c|c|c|c|c|c|c|c|c|}
\hline & 2001 & 2002 & 2003 & 2004 & 2005 & 2006 & 2007 & 2008 & 2009 & 2010 \\
\hline EU Net Exports & \multicolumn{10}{|c|}{ (Thousand MT) } \\
\hline Agenda 2000 & 442 & 441 & 438 & 436 & 438 & 441 & 449 & 447 & 444 & 441 \\
\hline Enlargement & 442 & 441 & 447 & 447 & 449 & 451 & 458 & 455 & 452 & 447 \\
\hline$\%$ Change & $0.0 \%$ & $0.0 \%$ & $1.9 \%$ & $2.5 \%$ & $2.5 \%$ & $2.1 \%$ & $1.9 \%$ & $1.8 \%$ & $1.6 \%$ & $1.4 \%$ \\
\hline \multicolumn{11}{|c|}{ New Zealand Net Exports } \\
\hline Agenda 2000 & 366 & 369 & 374 & 381 & 387 & 394 & 401 & 409 & 418 & 433 \\
\hline Change & 0.00 & 0.00 & -1.13 & -1.71 & -1.56 & -1.33 & -1.12 & -0.98 & -0.93 & -1.47 \\
\hline$\%$ Change & $0.0 \%$ & $0.0 \%$ & $-0.3 \%$ & $-0.4 \%$ & $-0.4 \%$ & $-0.3 \%$ & $-0.3 \%$ & $-0.2 \%$ & $-0.2 \%$ & $-0.3 \%$ \\
\hline \multicolumn{11}{|c|}{ Australia Net Exports } \\
\hline Agenda 2000 & 122 & 129 & 134 & 139 & 144 & 149 & 154 & 161 & 167 & 176 \\
\hline Enlargement & 122 & 129 & 134 & 139 & 144 & 149 & 154 & 160 & 166 & 175 \\
\hline$\%$ Change & $0.0 \%$ & $0.0 \%$ & $-0.4 \%$ & $-0.2 \%$ & $-0.2 \%$ & $-0.3 \%$ & $-0.4 \%$ & $-0.5 \%$ & $-0.5 \%$ & $-0.5 \%$ \\
\hline \multicolumn{11}{|c|}{ Argentina Net Exports } \\
\hline Agenda 2000 & & 102 & 105 & 107 & 109 & 111 & 112 & 115 & 117 & 119 \\
\hline Enlargement & 99 & 102 & 104 & 106 & 108 & 110 & 112 & 114 & 117 & 119 \\
\hline$\%$ Change & $0.0 \%$ & $0.0 \%$ & $-0.8 \%$ & $-0.9 \%$ & $-1.0 \%$ & $-0.8 \%$ & $-0.8 \%$ & $-0.7 \%$ & $-0.6 \%$ & $0.0 \%$ \\
\hline \multicolumn{11}{|c|}{ Brazil Net Imports } \\
\hline Agenda 2000 & 95 & 97 & 101 & 103 & 107 & 112 & 118 & 119 & 121 & 127 \\
\hline Enlargement & 95 & 97 & 103 & 106 & 110 & 114 & 120 & 121 & 123 & 127 \\
\hline$\%$ Change & $0.0 \%$ & $0.0 \%$ & $2.5 \%$ & $2.6 \%$ & $2.4 \%$ & $1.8 \%$ & $1.7 \%$ & $1.6 \%$ & $1.3 \%$ & $0.0 \%$ \\
\hline
\end{tabular}





\section{References}

Albiac J., and P. Garcia. "The Effects of Spain Entry into the European Community on the Spanish Hog Market," European Review of Agricultural Economics 19 (1992): 455-71.

Anderson, K. and R. Tyers. "Implications of EU Expansion for European Agriculture," In Expanding Membership of European Union, R. Baldwin, P. Haaparanta, and J. Kiander, eds., Cambridge University Press, 1995.

Baldwin, R., P. Haaparanta, and J. Kiander, eds. Expanding Membership of the European Union. Cambridge University Press, 1995.

Benjamin, C., A. Gohin and H. Guyomard (2000). "The Future of EU Dairy Policy," Canadian Journal of Agricultural Economics (this volume) forthcoming.

Chevassus-Lozza, E., J. Gallezot, and M. Harel. "Les Effets de l'Elargissement de l'Union Européenne aux PECO sur les Marchés Agricoles et Agro-Alimentaires," Rapport Final, Institut National de la Recherche Agronomique, Nantes and Ivry/Seine, November 1998.

Council of the European Union. "Council Regulation (EC) No 1256/1999," Official Journal of the European Communities, L160 (June 26, 1999): 73-79.

Directorate General VI (Agriculture). 1999a. "Agriculture Council: Policy Agreement on CAP Reform.” DG VI Newsletter (Special Edition), March 11, 1999 http://europa.eu.int/comm/dg06/publi/newsletter/spec1_en.htm, June 14, 1999.

Directorate General VI (Agriculture). 1999b. "Berlin European Council: Agenda 2000, conclusions of the Presidency." DG VI Newsletter (10), March 1999 June 14, 1999. http://europa.eu.int/comm/dg06/publi/newsletter/10 en.htm.

European Commission. "Agenda 2000. The Effects on the Union's Policies of Enlargement to the Applicant Countries of Central and Eastern Europe. Part II -. Analysis.” April 1999. http://europa.eu.int/comm/dgla/enlarge/agenda2000 en/impact/24.htm

Food and Agricultural Policy Research Institute (FAPRI). 1999a. FAPRI 1999 World Agricultural Outlook. Staff Report 2-99, Ames, Iowa.

1999b. "Analysis of European Dairy Policy Options with Additional Focus on Broader Effects of Agenda 2000”, mimeo, University of Missouri-Columbia. 
Josling, T., D. Kelch, P. Liapis, and S. Tangermann. "Agriculture and European Union Enlargement." USDA-Economic Research Service Technical Bulletin Number 1865, February 1998, Washington D.C.

Leetma, Susane., Elizabeth A. Jones, and Ralph Seeley. "Enlargement of the European Union to Central and Eastern Europe: Obstacles and Possible Consequences of Policy Harmonization." In Regional Trade Agreements and U.S. Agriculture, Mary Burfisher and Elizabeth Jones, eds., USDA-Economic Research Service Agricultural Economic Report Number 771, November 1998, Washington D.C.

Monke, Eric, Francisco Avillez, Roger Fox, Jimmye Hillman, Mark Langworthy, Jeff Bentley, Timothy Finan, Timothy Josling, Scott Pearson, and Stefan Tangermann. "Portugal on the Brink of Europe: The CAP and Portuguese Agriculture," Journal of Agricultural Economics 37(3) (1986): 317-331.

Pouliquen, Alain. "Agricultural Enlargement of the EU under Agenda 2000: Surplus of Farm Labor Versus Surplus of Farm Products," Economics of Transition, 6(November 1998) 2: 505-522.

Senior Nello, S., and K. A. Smith. The European Union and Central and Eastern Europe. The Implications of Enlargement in Stages. Brookfield, VT: Ashgate Publishing Company, 1998.

Westhoff, P., and R. Young. "Implications of the Berlin Accord for EU Agriculture." FAPRIUMC Report XX-99, University of Missouri--Columbia, May 1999. 


\section{Endnotes}

${ }^{1}$ For some commodities in some countries, import and export demands are specified separately. ${ }^{2}$ Leetma et al. employ a similar assumption in their enlargement analysis. 